\title{
TGF- $\beta$, Bone Morphogenetic Protein, and Activin Signaling and the Tumor Microenvironment
}

\author{
Michael W. Pickup, ${ }^{1}$ Philip Owens, ${ }^{2}$ and Harold L. Moses \\ Department of Cancer Biology and Vanderbilt-Ingram Comprehensive Cancer Center, Nashville, \\ Tennessee 37232 \\ Correspondence: hal.moses@vanderbilt.edu
}

The cellular and noncellular components surrounding the tumor cells influence many aspects of tumor progression. Transforming growth factor $\beta$ (TGF- $\beta$ ), bone morphogenetic proteins (BMPs), and activins have been shown to regulate the phenotype and functions of the microenvironment and are attractive targets to attenuate protumorigenic microenvironmental changes. Given the pleiotropic nature of the cytokines involved, a full understanding of their effects on numerous cell types in many contexts is necessary for proper clinical intervention. In this review, we will explore the various effects of TGF- $\beta$, BMP, and activin signaling on stromal phenotypes known to associate with cancer progression. We will summarize these findings in the context of their tumor suppressive or promoting effects, as well as the molecular changes that these cytokines induce to influence stromal phenotypes.

\begin{abstract}
A neoplasias progress to invasion and metasAtasis, specific microenvironmental changes are intricately involved in driving the process. In breast cancer, alterations in stromal gene expression are associated with progression from ductal carcinoma in situ (DCIS) to invasive ductal carcinoma (IDC) stages of cancer and correlate with poor patient prognosis (Ma et al. 2009). These changes are determined by alterations in infiltration and functions of cells that are found in the tumor microenvironment and ultimately result in phenotypic variations, which can either impede or promote epithelial cell malignancy. Phenotypic microenvironmental changes associated with enhanced tumor progression include desmoplasia, angiogenesis, inflammation, and suppression of antitumorigenic adap-
\end{abstract}

tive immune cell responses (Hanahan and Coussens 2012). Each of these processes can promote continued tumor growth. Mediated by the overactivation of resident and infiltrating fibroblasts, desmoplasia is the excessive deposition of extracellular matrix (ECM) proteins, which involves not only the production of ECM proteins but also the posttranslational modifications of these proteins necessary for stable ECM deposition (Kalluri and Zeisberg 2006). Such changes provide a scaffold for the infiltration of other cells and a substrate for tumor cell migration. When a tumor lacks necessary nutrient availability to maintain homeostasis, angiogenesis is induced to promote increased nutrient availability and facilitate continued tumor growth (Bergers and Benja-

\footnotetext{
${ }^{1}$ Present address: Center for Bioengineering and Tissue Regeneration, University of California, San Francisco, California 94143. ${ }^{2}$ Present address: Tennessee Valley Healthcare System, Department of Veterans Affairs, Nashville, Tennessee 37212. Editors: Rik Derynck and Kohei Miyazono Additional Perspectives on The Biology of the TGF- $\beta$ Family available at www.cshperspectives.org 
M.W. Pickup et al.

min 2003). This process involves the stimulation of endothelial cell proliferation and cellcell junction formation to adequately disseminate nutrients to tumor cells (Hida et al. 2008). Inflammation is a physiologic response to repair stressed or wounded tissue and is characterized by the influx of innate immune cells and subsequent release of growth factors and other proteins that promote tumor cell growth and migration and facilitate further alterations in the tumor microenvironment (Vesely et al. 2011). Of particular note is that tumors shift the phenotype of inflammatory cells toward a protumorigenic state rather than acting in an antitumorigenic fashion. The antitumoral immune responses attempt to clear the aberrant tissue, and tumors therefore must overcome the innate immune system to progress. To do this, tumors inhibit functions of the cellular mediators of the adaptive immune responses to allow continued malignant growth (Hanahan and Weinberg 2000).

Although the above processes have been identified and explored in the context of tumor progression, there remains a relatively poor understanding of the factors that drive these characteristics. Transforming growth factor $\beta$ (TGF- $\beta$ ) signaling is an essential component of epithelial induction of stromal activation, and provides the molecular signals that induce the stromal cells to elicit these phenotypic responses during tumor progression (Pickup et al. 2013a). Overexpression of TGF- $\beta$ ligands in tumor tissue is associated with poor patient prognosis in prostate cancer (Wikström et al. 1998). TGF- $\beta$ signaling has a complex role in directing tumor progression with the prevailing view that active TGF- $\beta$ signaling in the tumor epithelium suppresses tumorigenesis early, through inhibition of cellular proliferation, but promotes tumor progression through induction of an epithelial-to-mesenchymal transition (EMT) and increased tumor cell migration and invasion (Massague 2008). However, it is interesting to note that decreased expression of TGF- $\beta$ signaling mediators is associated with poor prognosis in numerous cancer types (Woodford-Richens et al. 2001; Pinto et al. 2003; Paiva et al. 2012; Owens et al. 2014). This could be caused by increased availability of ligands in tumor tissue to induce changes not only in the tumor epithelium but also in the stromal cells of the tumor microenvironment. In support of this hypothesis, a TGF- $\beta$-induced gene expression profile in numerous stromal cell populations predicts poor patient prognosis in colorectal cancer (Calon et al. 2012). This review will focus on the roles of the TGF- $\beta$ family in the alterations to the tumor microenvironment associated with tumor progression, with a focus on how different signaling ligands and receptors elicit similar and different phenotypic responses.

\section{EPITHELIAL-STROMAL INTERACTIONS}

The induction of stromal alterations during tumor progression is driven by numerous cell types, particularly by the tumor cells themselves. Distinct oncogenic mutations and signaling changes in response to extracellular cues from the microenvironment produce variable phenotypic changes as tumors progress. Along with its many tumor cell-intrinsic functions, TGF- $\beta$ signaling in tumor cells also induces significant changes in the tumor microenvironment through alterations in the expression of various proteins, including secreted factors (Table 1) (Pickup et al. 2013a). In transgenic mice with constitutively active TGF- $\beta$ signaling because of ligand overexpression or mutation of the type I TGF- $\beta$ receptor T $\beta$ RI/ ALK-5 receptor, epithelial cells direct the phenotypic outcome of significant stromal changes, such as enhanced collagen deposition and angiogenesis (Muraoka-Cook et al. 2006; Safina et al. 2007). These stromal changes are associated with increased expression of cytokines and chemokines by the epithelial cells. These secreted factors influence stromal activation through differentiation of resident cells, alteration of noncellular tissue components, as well as recruitment of various mesenchymal and lymphocytic cells. For example, signaling by T $\beta$ RI/ ALK-5 increases matrix metalloproteinase (MMP) expression, which is associated with increased angiogenesis in vivo (Safina et al. 2007). Active TGF- $\beta$ signaling in epithelial cells promotes an angiogenic phenotype through the 
TGF- $\beta$ Signaling in the Tumor Microenvironment

Table 1. Transforming growth factor $\beta$ (TGF- $\beta$ )-induced genes with known roles in microenvironmental modulation

\begin{tabular}{llll}
\hline Stromal phenotype & Genes & Regulation & \multicolumn{1}{c}{ References } \\
\hline Desmoplasia & ADAM19 & Increased & Wei et al. 2001 \\
& COL1A1 & Increased & Lijnen and Petrov 2002 \\
COL5A1 & Increased & Roepman et al. 2005 \\
& LOXL2 & Increased & Barry-Hamilton et al. 2010 \\
TAGLN & Increased & Yu et al. 2013 \\
THBS1 & Increased & Bein and Simons 2000 \\
& ANGPTL4 & Increased & Okochi-Takada et al. 2014 \\
Angiogenesis & Increased & Steg et al. 2011 \\
& SEMA3C & Increased & Ellis 2006 \\
& THBS1 & Increased & Simantov and Silverstein 2003 \\
& VEGFA & Increased & Nakagawa et al. 2004 \\
CEBPD & Decreased & Duitman et al. 2014 \\
CXCL1 & Decreased & Bierie et al. 2009 \\
Inflammation & CXCL5 & Decreased & Bierie et al. 2009 \\
& IL11 & Increased & Yashiro et al. 2006 \\
& CD73 & Increased & Beavis et al. 2012 \\
& SDF1A & Increased & Karin 2010 \\
\hline
\end{tabular}

TGF- $\beta$ signaling drives tumor cell gene changes to influence stromal phenotypes. Significantly altered gene expression changes among three publicly available data sets obtained from TGF- $\beta$-treated carcinoma cells, and gene expression profiles from TGFBR2 $2^{-/-}$cancer cells (GSE23952, GSE17708, GSE10393; Bierie et al. 2009) were compared to derive a consensus of genes similarly altered in cancer cells on TGF- $\beta 1$ stimulation. These significantly altered genes were segregated into groups associated with the promotion of various stromal phenotypes.

increased expression and secretion of angiogenic factors, such as vascular endothelial growth factor (VEGF) and thrombospondin 1 (Wang et al. 2008a; Sartor et al. 2010). TGF- $\beta$ signaling is also associated with a desmoplastic response through induction of ECM remodeling genes, such as MMPs and lysyl oxidase-like 4 (LOXL4), as well as ECM components themselves (Wang et al. 2008a). There are also emerging mechanisms by which TGF- $\beta$ signaling in the tumor epithelium can alter immune responses through suppression of microRNA (miRNA) expression. Such data represent an exciting aspect of TGF$\beta$ signaling directing tumor-stromal interactions and tumor progression through altered miRNA biosynthesis. TGF- $\beta$ upregulates the expression of CCL22, a chemokine shown to promote trafficking and activation of Tlymphocytes to sites of inflammation, in hepatocellular carcinoma cells through the suppression of miR-34a expression, which correlates with increased regulatory T-cell (Treg) presence in the tissue (Yang et al. 2012). These activating effects are counteracted through inhibition of chemokine expres- sion resulting in a decreased inflammatory response. Studies involving either activation of the TGF- $\beta$ signaling pathway or targeted inactivation of TGF- $\beta$ signaling mediators have shown that TGF- $\beta$ signaling inhibits the secretion of immunomodulatory factors. Gene expression and functional analyses have established CXCL1 and CXCL5 as critical chemokines, whose expression is inhibited by TGF- $\beta$ signaling (Bierie et al. 2009). Deletion of TGF- $\beta$ signaling in mouse mammary epithelial cells by conditional inactivation of the Tgfbr2 gene, which encodes the type II TGF- $\beta$ receptor (T $\beta R I I)$, results in increased infiltration of myeloid cells, in particular $\mathrm{CD} 11 \mathrm{~b}^{+} \mathrm{Gr} 1^{+}$myeloidderived suppressor cells (MDSCs) (Yang et al. 2008). Ultimately, increased MDSC infiltration suppresses T-cell activity allowing for enhanced tumor progression through immune evasion. Interestingly, conditional inactivation of $T g f b r 2$ as well as expression of a dominant-negative T $\beta$ RII in mammary epithelial cells both result in stromal changes similar to those arising from activation of TGF- $\beta$ signaling and leading 
M.W. Pickup et al.

to more angiogenesis and collagen deposition (Amendt et al. 1998; Muraoka-Cook et al. 2006; Bierie et al. 2008). However, these stromal changes could be because of interactions between stromal cells and an altered cytokine environment elicited by the influx of myeloid cells.

Similar to TGF- $\beta$, bone morphogenetic protein (BMP) signaling in the tumor cells elicits epithelial as well as stromal changes. Clinical evidence in support of the stromal effects of $\mathrm{BMP}$ is apparent in juvenile polyposis, a disease characterized by germline mutations in the BMP type I receptor BMPRIA/ALK-3. Juvenile polyposis presents with dense stroma and increased infiltration of immune cells (Hardwick et al. 2008). However, the expression of BMP ligands is increased in patients with breast cancer and the expression of the BMP receptors BMPRIA and BMPRII correlates with a poor prognosis, indicating that BMP signaling in breast cancer cells remains intact and active during metastatic progression (Owens et al. 2014). With these data indicating that BMP signaling can act as a tumor promoter in breast cancer, it is interesting to note that, similar to TGF- $\beta$, the attenuation of BMPRII signaling in mammary carcinoma cells enhances metastasis (Owens et al. 2012). Such data underlie a key distinction between the cell autonomous and microenvironmental effects of the TGF- $\beta$ family signaling to elicit different results during tumor progression. As with TGF- $\beta$ signaling, a major change in the primary tumor with impaired BMP signaling and increased metastasis is a large influx of immune cells, notably $\mathrm{F} 4 / 80^{+}$macrophages and $\mathrm{Gr}-1^{+}$MDSCs. This increase in immune infiltration is the result of a significantly altered chemokine expression profile of the mammary tumor cells with impaired BMP signaling (Owens et al. 2012). The role of activin signaling may be similar to that of TGF- $\beta$ in that activin signaling mediators are largely inactivated in breast cancer, and downregulation of $A C V R 2 A$ and $A C V R 2 B$ encoding activin type II receptors correlates with a worse relapse-free survival (Owens et al. 2014). Further, studies of activin signaling in breast, liver, prostate, and pancreatic cancer cells show a growth inhibitory effect (Sozzani and Musso 2011). Unlike TGF- $\beta$ and
BMP signaling there is little evidence that down-regulation of activin signaling results in significant stromal changes. However, further investigations are needed to reveal the role of activin signaling in the tumor epithelium in regulating the tumor microenvironment.

\section{DESMOPLASIA}

The excessive deposition of ECM is commonly referred to as desmoplasia and is associated with many disease states. In the context of tumor initiation, desmoplasia is associated with an increased tumor occurrence, as well as increased progression of the disease. In cancer, a noted feature in the progression of the disease is the accumulation of stromal cells including fibroblasts expressing $\alpha$-smooth muscle actin $(\alpha-S M A)$, a microfilament protein associated with a mesenchymal morphology (Kalluri and Zeisberg 2006). These fibroblasts result from activation of resident or infiltrating fibroblasts, which then perform numerous functions in the tumor microenvironment. One of the most prominent features of fibroblasts in normal physiological function, as well as in cancer progression, is the deposition and remodeling of ECM proteins (Place et al. 2011). Increased mammographic density predicts increased development of breast cancer and promotes progression of the disease (Boyd et al. 2007). This mammographic density results from an increased deposition of collagen in the mammary tissue. As mentioned, microarray analysis of cancer-associated stroma has significantly impacted our understanding of the molecular changes that occur in the microenvironment during tumor progression. Interestingly, induction of ECM genes, most notably of those encoding collagens, in the stroma is associated with poor patient prognosis (Bergamaschi et al. 2008; Finak et al. 2008; Roman-Perez et al. 2012). Mouse models expressing mutations in the MMP targeting region of collagen corroborate these clinical findings. These mice present with tumors that have increased collagen deposition and ultimately lead to enhanced tumor cell metastasis (Provenzano et al. 2008). Not only the deposition of collagen influences tu- 
mor progression but also the posttranslational modifications are necessary for proper incorporation of ECM proteins into the ECM (Lu et al. 2012). Expression of collagen-cross-linking enzymes has been shown to promote tumor progression, specifically tumor cell metastasis, in mouse models of cancer (Paszek et al. 2005; Erler et al. 2006; Levental et al. 2009). The concept of collagen architecture and remodeling playing a role in tumor progression has been taken one step further through the use of second harmonic imaging, which has allowed collagen structure to be segregated into three phenotypic signatures based on collagen alignment and orientation, known as the tumor-associated collagen signature (TACS) (Provenzano et al. 2006). Specific changes outlined in these signatures are associated with invasion of mammary carcinoma cells. Given the importance of TGF- $\beta$ signaling in activating stromal fibroblasts, this pathway acts as a primary mediator of the various desmoplastic changes promoting tumor progression (Bierie and Moses 2006).

A TGF- $\beta$-induced expression profile in fibroblasts is the definition of an activated fibroblast and is critical in eliciting a desmoplastic response in the tumor microenvironment (Border and Noble 1994). Treatment of fibroblasts with TGF- $\beta$ induces the expression of $\alpha$-SMA as well as numerous ECM proteins, including type I collagen and fibronectin (Desmouliere et al. 1993). Consistent with these results, loss of TGF- $\beta$ responsiveness in fibroblasts impairs the ability of the cell to produce ECM proteins and remodel the ECM (Martinez-Ferrer et al. 2010 ). Comparing these roles of TGF- $\beta$ signaling in fibroblasts to tumor progression, we observe expected results. Increased expression of $\alpha$-SMA is associated with high levels of TGF- $\beta$ in squamous cell and other carcinomas (Kojc et al. 2005). Overexpression of TGF- $\beta 1$ in orthotopically injected human stroma results in the progression of normal breast epithelial cells to a hyperplastic phenotype (Kuperwasser et al. 2004). TGF- $\beta$ expression is in part controlled by the transcription factor heat shock factor 1 (HSF1), and this induction promotes the progression of breast cancer in a TGF- $\beta$-dependent manner (Scherz-Shouval et al. 2014). Addition- ally, the presence of TGF- $\beta$ ligand is associated with increased deposition of multiple ECM proteins, including fibronectin and tenascin, in invasive breast and cervical carcinomas (Walker et al. 1994; Hazelbag et al. 2002). The culmination of these TGF- $\beta$ actions results in a gene signature that drives specific gene expression changes in stromal fibroblasts (Calon et al. 2012). These changes have been identified in carcinomas and used to generate an ECM gene signature that is associated with poor patient prognosis (Bergamaschi et al. 2008). Interestingly, clinical and experimental data show that TGF- $\beta$ signaling in fibroblasts is also tumor suppressive and that loss of TGF- $\beta$ signaling components is associated with tumor progression and can even promote spontaneous tumor formation, particularly through the creation of an inflammatory microenvironment (Bhowmick et al. 2004; Achyut et al. 2013; Busch et al. 2015). Immune regulation represents another means by which fibroblasts can influence tumor progression in addition to their ability to cause desmoplastic stromal changes. Fibroblasts not only play a role in orchestrating the final stages of wound healing but act as professional secretory cells directing the appropriate cellular chemokines and cytokines for immune cell recruitment and elimination.

Other TGF- $\beta$ family members have similar roles in fibroblast function; however, the substantial complexity and limited amount of data make their role in the desmoplastic phenotype of cancer poorly defined. BMPs are a prime example of complexity with various ligands associated with differing functional responses from fibroblasts. For example, BMP-7 has been shown to inhibit fibroblast activation in corneal fibroblasts, whereas BMP-4 induces the expression of the ECM proteins collagen and laminin in mammary-derived fibroblasts (Izumi et al. 2006; Owens et al. 2013). Additionally, BMP functions to suppress chemokine expression. Loss of BMP signaling in fibroblasts increases expression of CCL5/RANTES and granulocyte-colony-stimulating factor (GCSF/CSF3) to promote infiltration of myeloid cells into the tumor microenvironment (Pickup et al. 2015). Activin signaling appears to have 
M.W. Pickup et al.

activities similar to TGF- $\beta$, with treatment of fibroblasts with TGF- $\beta$ inducing higher $\alpha$ SMA and collagen expression, and increased $\alpha$-SMA immunostaining being associated with increased collagen deposition (Fumagalli et al. 2007; Mukhopadhyay et al. 2007). Tumor initiation and progression from DCIS is associated with activin $\mathrm{A}$-induced fibroblast activation and ECM synthesis. Additionally, high levels of activin A associate with increased desmoplasia surrounding the foci of epithelial neoplasia (Fordyce et al. 2012; Dumont et al. 2013). The phenotypic changes induced by TGF- $\beta$ family stimulation of stromal fibroblasts also promotes tumor progression through inhibition of tumor cell apoptosis and induction of tumor cell migration (Jinka et al. 2012).

Although production of ECM proteins is a critical hallmark of a desmoplastic tumor microenvironment, posttranslational remodeling is also an essential component in the development of a tumor-promoting desmoplastic microenvironment. Identified as an important part of the wound healing process, an essential function of fibroblasts is their ability to remodel and contract a collagen matrix (Kalluri and Zeisberg 2006). The aforementioned tumor-associated collagen signature depends on active production of enzymes involved in the modification of ECM components and the cells' ability to interact with the modified collagen (Provenzano et al. 2006). Processes such as maturation or degradation of collagen fibers play essential roles in determining tumor progression. Secreted protein, acidic, cysteine-rich (SPARC) and lysyl oxidase (LOX) are examples of matrix modifying enzymes that stabilize ECM components with well-established roles in the progression of the disease (Reed et al. 1994; Payne et al. 2007). TGF- $\beta$ treatment of fibroblasts is associated with an increase in the expression of both of these enzymes (Boak et al. 1994; Reed et al. 1994). For example, SPARC is found in the ECM gene signature associated with TGF- $\beta$ signaling and poor patient prognosis (Calon et al. 2012). Additionally, TGF- $\beta$ induces LOX expression in both lung and mammary fibroblasts to promote tumor metastasis (Boak et al. 1994; Pickup et al. 2013b). The ultimate culmination of the induced expression of these genes is the stiffening of the ECM in the tumors, which results in enhanced EMT and increased invasion and metastasis of tumor cells (Fig. 1) (Leight et al. 2012; Baker et al. 2013).

Other TGF- $\beta$ family ligands have not been associated with this type of ECM remodeling, but are associated with increased expression of genes involved in ECM degradation. The most prominent protein families associated with ECM degradation are the MMPs and the ADAMTS (a disintegrin and metalloproteinase with thrombospondin motif) proteins. TGF- $\beta$ itself is an essential driver of the expression of both of these families of proteins, most notably MMP2 and MMP9 (Chambers et al. 2003; Dang et al. 2004). The evidence for involvement of BMPs as well as activins in the induction of ECM degradation enzymes is similar to that with TGF- $\beta$ inducing the expression of numerous MMPs as well as ADAMTS proteins (Yamashita et al. 2004; Fessing et al. 2010; Owens et al. 2013). It is interesting to note that increased expression of either ECM stabilization or degradation enzymes is associated with enhanced tumor progression and poor patient prognosis (Murray et al. 1996; Erler et al. 2006). However, the effects of these stabilizing and degrading factors in the context of TGF- $\beta$ family signaling, particularly BMP and activin signaling, on the composition and architecture of the tumor ECM remain to be elucidated.

\section{ANGIOGENESIS}

As carcinomas grow in size, more nutrients are required to maintain an environment that will sustain cell survival and growth. At first tumors are small enough to survive off the nutrients provided by the existing vasculature. However, as they reach a size of approximately one centimeter, the limited nutrient availability is unable to sustain continued tumor growth, and a hypoxic environment develops (Bergers and Benjamin 2003). Hypoxia, a lack of oxygen availability, influences tumor progression through induction of EMT and tumor cell invasion (Zhou et al. 2006). Hypoxic cues also drive the expression of angiogenic factors to promote 

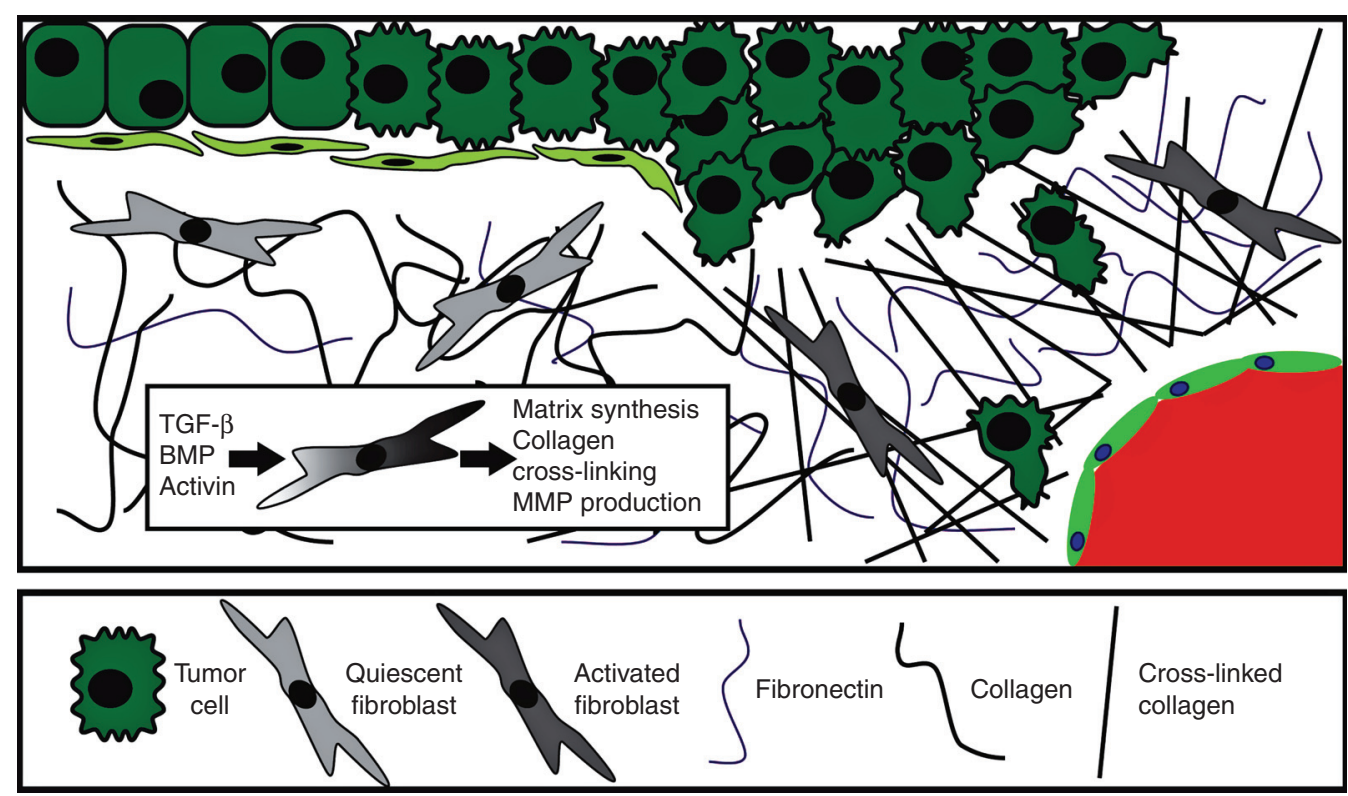

Figure 1. Transforming growth factor- $\beta$ (TGF- $\beta$ ) family signaling promotes fibroblast activation and function to drive a desmoplastic stromal response. TGF- $\beta$, bone morphogenetic protein (BMP), and activin signaling drive the activation of fibroblasts to promote stromal changes, including increased extracellular matrix (ECM) production and remodeling. Overall, these changes are associated with highly invasive tumors and promote epithelial changes including increased proliferation, epithelial-to-mesenchymal transition (EMT), and invasion as well as angiogenesis leading to increased metastasis.

the sprouting and spreading of existing vasculature, known as the angiogenic switch. The angiogenic process involves two essential steps, induction of endothelial cell proliferation and migration and maturation of vessels through the establishment of endothelial cell-cell contacts and pericyte coverage. A primary driver in the expansion of the vascular network is the secreted VEGF, which promotes endothelial cell proliferation and maturation of expanded blood vessels (Franses et al. 2011). The central role of VEGF in angiogenesis provides the basis for therapeutic intervention in tumor patients using the drug bevacizumab (Ferrara et al. 2004). This humanized anti-VEGF antibody is used as an adjuvant therapeutic for colorectal and lung cancer as well as glioblastoma.

Targeted inactivation of the expression of Smad4, a central mediator in Smad signaling, specifically in endothelial cells results in a failure to form tube structures in vitro and in embryonic lethality in vivo (Lan et al. 2007). Given the pleiotropic nature of these cytokines, numerous members of the TGF- $\beta$ family play an important role in the angiogenic process in tumor progression. Breaking down the TGF- $\beta$ family into specific signaling ligands, TGF- $\beta$ significantly controls tumor angiogenesis. In a physiological context, activation of signaling and depletion of signaling components in the TGF- $\beta$ pathway both result in significantly altered vascular phenotypes (Oshima et al. 1996; Lebrin et al. 2005; Allinson et al. 2012). Additionally, under hypoxic conditions, TGF- $\beta$ and BMP signaling are increased and help resolve the hypoxic environment (Falanga et al. 1991; Akman et al. 2001; Maegdefrau et al. 2009).

In the context of tumor development, experimental models as well as human cancers that express high levels of TGF- $\beta$ are associated with increased expression of proangiogenic factors and an overall increase in blood vessel formation (Pardali and ten Dijke 2009). TGF- $\beta$ inhibition reverses this angiogenic phenotype 
M.W. Pickup et al.

(Mazzocca et al. 2009; Zhang et al. 2011). This induction occurs through both direct and indirect effects of TGF- $\beta$ on endothelial cells. Directly, TGF- $\beta$ has been shown to stimulate endothelial cell migration and maturation (Yang and Moses 1990). These phenotypic responses are attributed to effects of TGF- $\beta$ signaling on miRNA processing and production. Treatment of endothelial cells as well as vascular smooth muscle cells with TGF- $\beta$ induces a contractile phenotype. This contractile phenotype is in part caused by effects of TGF- $\beta$ signaling on the expression and processing of miR-21 and miR-29a, resulting in an increase in their activities (Davis et al. 2008). The overall result of TGF- $\beta$ signaling in endothelial cells leads to enhanced expression of miRNAs and induction of a contractile phenotype, and an enhancement of angiogenesis. Indirectly, TGF- $\beta$ has been shown to induce the expression of other angiogenic factors, particularly VEGF, in tumor and stromal cells (Pepper 1997). However, TGF- $\beta$ signaling has also been shown to inhibit these proangiogenic phenotypes in endothelial cells. These differential effects are controlled by the TGF- $\beta$ coreceptors betaglycan (also known as TGF- $\beta$ type III receptor) and endoglin, which modulate an endothelial cell's response to TGF$\beta$ between inducing either Smad2 and Smad3 or Smad1 and Smad5 activation and nuclear translocation, resulting in differential transcriptional activity (Pardali et al. 2010). In response to TGF- $\beta$ stimulation, the coreceptor betaglycan promotes Smad 2 and Smad3 phosphorylation by the type I TGF- $\beta$ receptor T $\beta$ RI/ALK- 5 to inhibit endothelial cell proliferation and migration. However, the coreceptor endoglin alters this response by inducing phosphorylation by another type I receptor, ALK-1, which in turn phosphorylates Smad1 and Smad5 to induce endothelial cell proliferation and migration. Although induction of Smad2 and Smad3 phosphorylation in response to TGF- $\beta$ inhibits endothelial cell proliferation and migration, induction of Smad1 and Smad5 phosphorylation, in response to TGF- $\beta$ in the presence of endoglin, promotes the proangiogenic phenotypes. BMPs, which activate Smad1 and Smad5, have also been shown to promote angiogenesis dur- ing tumor progression (Raida et al. 2005; Liu et al. 2007).

Acting in a similar fashion as TGF- $\beta$, BMPs, specifically BMP-4, -7 , and -9 , stimulate endothelial cell proliferation and tube formation in cell culture (Suzuki et al. 2008). This endothelial cell response to BMPs may require cooperation with VEGF signaling (David et al. 2007; Bieniasz et al. 2009). Evidence for a role of activin signaling in endothelial cell function suggests an inhibitory role of this ligand in angiogenesis. Several studies show that stimulation of endothelial cells with activin inhibits cell proliferation (McCarthy and Bicknell 1993; Panopoulou et al. 2005). As with TGF- $\beta$ stimulation, activin acts through Smad 2 and Smad3 supporting the notion that the differential response of endothelial cells to this family of ligands is primarily defined by the internal signaling components.

Proliferation and migration are only the first steps in the angiogenic process. The formation of a complete and functional blood vessel involves the inhibition of proliferation and migration, and the formation of cell-cell junctions and induction of pericyte coverage. As mentioned, the effects of TGF- $\beta$ family signaling control this resolution of angiogenesis, and correlate with the overall effects of active TGF- $\beta$ signaling on tumor vessel formation. The large majority of experimental models of tumor progression and human patients correlate high levels of TGF- $\beta$ expression with increased vasculogenesis, when compared with control tumors that have lower TGF- $\beta$ levels (Tuxhorn et al. 2002; Mazzocca et al. 2009; Hawinkels et al. 2010). However, as TGF- $\beta$ has dual effects on endothelial cell function, it is not surprising that there are reports of TGF- $\beta$ inhibiting tumor angiogenesis (Geng et al. 2013). It has been shown that inhibition of TGF- $\beta$ signaling causes normalization of tumor vasculature with improved pericyte coverage of blood vessels and perfusion (Fig. 2) (Min et al. 2012).

BMP and activin signaling have also been implicated in angiogenesis. Implantation of tumor cells expressing high levels of BMPs was shown to promote angiogenesis in the resulting tumors, and increased expression of the BMP inhibitor, noggin, suppresses angiogenesis 

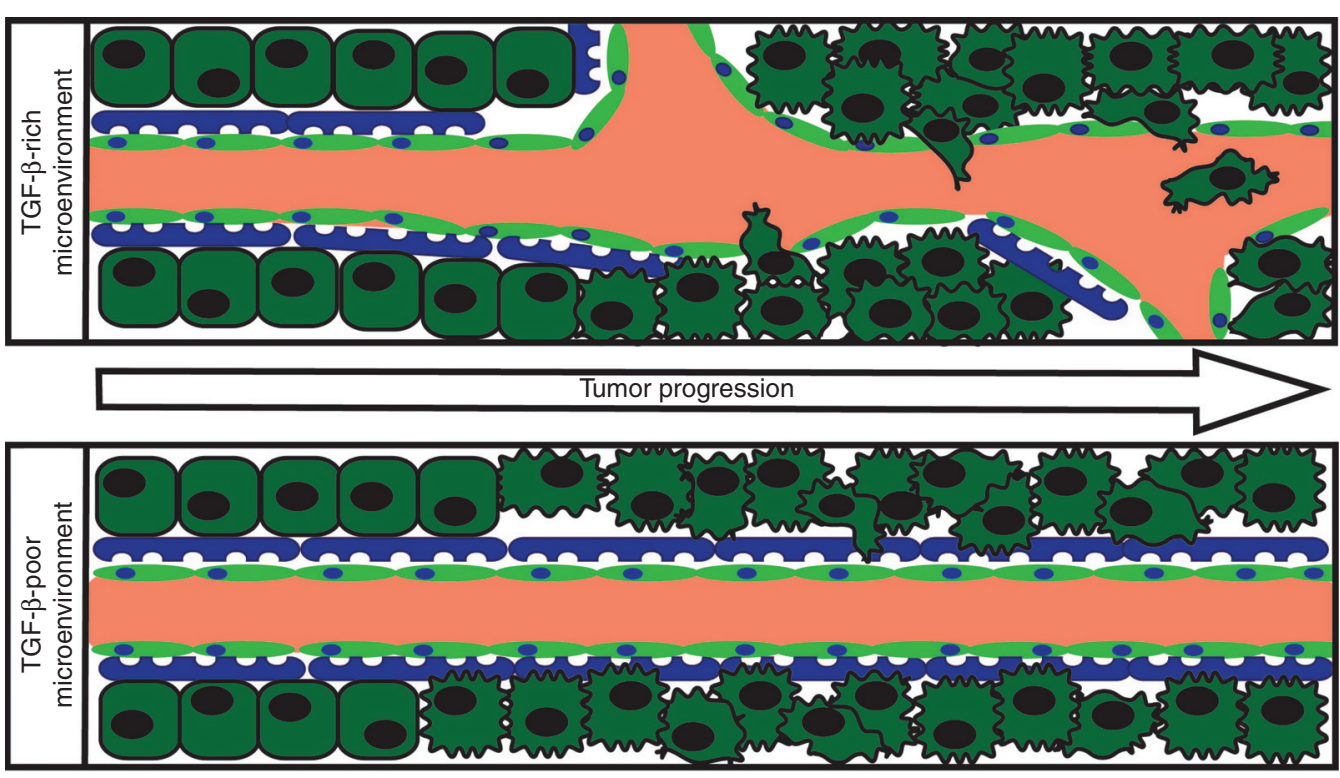

Figure 2. Inhibition of transforming growth factor $\beta$ (TGF- $\beta$ ) proangiogenic functions normalizes aberrant vessel formation associated with tumor progression. As tumors progress, endothelial cell proliferation and migration are required to provide nutrients to the increased demand in a growing tumor. Signaling by members of the TGF- $\beta$ family has been shown to drive this process, thus introducing the potential for inhibition of this signaling axis to stunt blood vessel formation and thus slow tumor growth, spread, and potentially response to chemotherapeutics.

(Langenfeld and Langenfeld 2004). In addition, BMP expression positively correlates with VEGF expression in lung cancer patients (Bieniasz et al. 2009). Furthermore, neuroblastomas overexpressing activin A show decreased tumor growth that correlates with fewer capillaries (Panopoulou et al. 2005). Research on BMP and activin signaling in tumors has not yet established whether their angiogenic effects promote pericyte coverage and proper vessel perfusion. However, genetic ablation of Smad5, a cell-signaling mediator of the BMP response, results in numerous developmental abnormalities including improper formation of an intact vascular system (Chang et al. 1999). Additional developmental biology research shows that inhibition of BMP signaling and other TGF- $\beta$ family signaling reduces angiogenesis in developing embryos, and suggests that this may also be true in tumors (Guillot et al. 2012). Further studies are needed to strengthen these correlations. Further evidence suggests that coreceptors mediate the angiogenic response by induc- ing differential Smad phosphorylation. Thus, an additional layer of context is important to understand the dual response of endothelial cells to TGF- $\beta$ signaling. Such data would be imperative to understand the role TGF- $\beta$, BMP and activin signaling in angiogenesis, and may provide new avenues for intervention into this tumor promoting process (Pardali et al. 2010). Although TGF- $\beta$ is associated with enhanced angiogenesis in numerous studies, it would be interesting to determine whether this was through direct induction of an angiogenic response or through altering the signaling response of the cells to other TGF- $\beta$ family ligands such as BMPs (Wiley et al. 2011).

\section{INFLAMMATION AND THE IMMUNE RESPONSE}

The TGF- $\beta$ family is a critical regulator of immune responses in normal homeostasis as well as disease states. These effects are induced by alterations of immune cell recruitment, differ- 
M.W. Pickup et al.

entiation, and function. Targeted inactivation of Smad4 expression, resulting in impaired Smad signaling by the TGF- $\beta$ family, in bone marrow cells results in a failure to develop normally functioning cells differentiated from hematopoietic stem cells (Karlsson et al. 2007). Mice with germline deficiency in the expression of TGF- $\beta 1$ show a marked inflammatory response mediated by altered lymphocyte cell function to promote innate cell activation (Kulkarni et al. 1993; Diebold et al. 1995). Conversely, systemic inactivation of T $\beta$ RII expression leads to overactivation of the adaptive immune system associated with autoimmune disease (Oshima et al. 1996). Expression of a dominant-negative type II TGF- $\beta$ receptor, T $\beta$ RII, in $\mathrm{CD} 8^{+} \mathrm{T}$ cells results in a significant expansion of this cell population caused by a lack of the antiproliferative effects of TGF- $\beta$ on the T cells (Lucas et al. 2000). Genetic ablation of Smad4 in $\mathrm{CD}^{+}{ }^{+}$cell populations in vivo promotes the development of spontaneous gastrointestinal carcinomas (Kim et al. 2006).

In tumor progression, various cell populations of the immune system can have either proor antitumorigenic effects, depending on the context of cell maturation and function. These functions can largely be broken down by the adaptive and innate immune cell populations of the immune system. The innate immune system recognizes foreign antigen and promotes a general inflammatory microenvironment, whereas the adaptive immune system recognizes specific foreign antigens and kills off infected cells to prevent spread of foreign entities (Vesely et al. 2011). The TGF- $\beta$ family significantly alters both innate and adaptive immune cell phenotypic responses with the outcome being largely protumorigenic through numerous mechanisms, including differentiation of T cells into Th17 and Treg cells, as well as macrophages into M2 identified cells.

\section{ADAPTIVE IMMUNE RESPONSE}

Despite being derived from "self-tissue," tumor development can be associated with mutations that result in the production of abnormal proteins. Most cells can display antigens at their cell surface, but dendritic cells in particular process proteins and display antigenic peptides in the context of presentation of major histocompatibility complex (MHC) proteins at their cell surface for potential recognition by T cells (Palucka and Banchereau 2012). This process represents a significant hurdle that the tumors must overcome lest they elicit an antitumorigenic adaptive immune response (Hanahan and Weinberg 2000). Although numerous factors can be influenced by a tumor to alter this adaptive immune response, and could induce T-cell-mediated cytotoxic action, this section will focus only on the adaptive immune system. TGF- $\beta$ is an essential factor used by the tumors to suppress tumordirected T-cell activation (Li and Flavell 2008). This function is achieved through action at several steps, with one of the first being the suppression of antigen presentation by $\mathrm{MHC}$ proteins on antigen presenting cells.

Acting to prevent the potential presentation of tumor antigens to the adaptive immune system, TGF- $\beta$ suppresses not only the infiltration of antigen presenting dendritic cells into tumors, but also the ability of these cells to present antigens to $\mathrm{T}$ cells (Byrne et al. 2008; Novitskiy et al. 2012). Thus, as expected, alleviating this suppressive effect, through targeted inactivation of T $\beta$ RII expression in dendritic cells, or suppression of TGF- $\beta$ signaling by administration of the TGF- $\beta$ inhibitory molecule SB-431542, induces antigen presentation as well as T-cell activation (Tanaka et al. 2010). Given that TGF- $\beta$ promotes an immune suppressed microenvironment, targeted inhibition of TGF- $\beta$ signaling in immune cells could lead to enhanced function of antigen presenting cells (APCs) and cytotoxic T lymphocytes (CTLs). It should be noted that the SB-431542 compound acts broadly to repress several TGF- $\beta$ family type I receptors (i.e., ActRIB/ALK-4, T $\beta R I /$ ALK-5, and ALK-7) (Inman et al. 2002), which may suggest similar actions of activin and TGF$\beta$ signaling in dendritic cell function.

BMP stimulation of dendritic cells promotes the activities of the cellular components of the adaptive immune system by inducing the expression of interleukin 8 (IL-8) and tumor necrosis factor $\alpha$ (TNF- $\alpha)$ (Martinez et al. 2011). 
Additionally, BMP stimulation of dendritic cells increases the expression of the maturation markers programmed cell death 1 ligand 1 (PDL1) and PD-L2, which promote T-cell and natural killer (NK) cell stimulation (Martinez et al. 2014). This once again points to similar effects of TGF- $\beta$ and activin in the suppression of APC cell function, whereas BMP opposes this with stimulation of dendritic cell activity. Although these data are still preliminary and need further validation, it will be interesting to see if this could be because of differences in signaling pathways to mediate different phenotypic effects or cooperation with other signaling pathways unique to certain cell types.

An additional level of regulation of adaptive immune cell function by the TGF- $\beta$ family is the expansion of a T-cell population in response to "non-self" antigens. As mentioned, systemic inactivation of the $T g f b 1$ gene leads to myeloproliferative disorders (Yaswen et al. 1996). This results in the development of autoimmune disease, implying that TGF- $\beta$ in the context of T-cell development during tumorigenesis suppresses the proliferation of activated $\mathrm{T}$ cells. Indeed, TGF- $\beta$ inhibits T-cell proliferation, as is apparent from experiments with enhanced TGF- $\beta$ signaling or suppression using a dominant-negative T $\beta R I I$ in T cells (Gorelik and Flavell 2000; Lucas et al. 2000). However, the number of $\mathrm{T}$ cells in the tumor microenvironment is not the only determinant of the protumorigenic function of TGF- $\beta$ on T cells. TGF- $\beta$ also inhibits the priming of $\mathrm{T}$ cells to an activated state that enables the cells to react to foreign antigens and elicit cytotoxic effects (Xu et al. 2003; Filippi et al. 2008; Oleinika et al. 2013). On identification of a "non-self" antigen, naïve $\mathrm{T}$ cells are primed into a Th1 cell phenotype to induce phagocytic-cell-mediated inflammation, or a Th2 cell phenotype to promote antibody production to potentiate a further immune response against the recognized antigen (Germain 2002). TGF- $\beta$ suppresses the phenotypic development of both these cell types at a second level, stunting the function of $\mathrm{T}$ cells and its potential action against tumor cells (Gunturi et al. 2005; Bommireddy et al. 2006; Li et al. 2007; Li and Flavell 2008).
TGF- $\beta$ Signaling in the Tumor Microenvironment

A third level of TGF- $\beta$-mediated T-cell suppression occurs in the induction of a differentiation program in $\mathrm{T}$ cells, which suppresses the activity of T cells. TGF- $\beta$ plays an essential role in the development of Treg cells as well as Th17 cells in a Smad-dependent manner (Chen et al. 2003; Takimoto et al. 2010). Exposure of naïve T cells to TGF- $\beta$ induces the expression of the Foxp3 transcription factor to prompt a cellular phenotype associated with suppression of CTL function. The primary mechanism by which CTL function is suppressed is through increased expression of TGF- $\beta 1$ (Whiteside et al. 2012). Alternatively, in an environment that is enriched in IL- 6 , the addition of TGF- $\beta$ causes a phenotypic switch toward a Th17 cell phenotype. The inducing factors that drive Th17 cell differentiation determine whether they invoke pro- or antitumorigenic responses. TGF- $\beta$ has been shown to induce a Th17 cell type, which is largely suppressive of antitumor immunity. Through the main effector, IL-17, this differentiation state results in a phenotypic outcome of suppressed T-cell activity (Mangan et al. 2006; Chalmin et al. 2012). The overall protumorigenic function of TGF- $\beta$ in shifting T-cell differentiation has led to significant strides in research and clinical trials aimed at inhibiting these functions for the benefit of the patient (Akhurst and Hata 2012).

Preclinical trials with various TGF- $\beta$ inhibitory small molecules and antibodies show that their therapeutic usage results in an antitumorigenic response that is generally associated with a more active adaptive immune system (Akhurst and Hata 2012). Interestingly, activin signaling cooperates with TGF- $\beta$ to promote an immune suppressive environment. Specifically, the TGF$\beta$-induced conversion of naïve $\mathrm{T}$ cells into Foxp3-expressing Treg cells is significantly enhanced when activin $\mathrm{A}$ is added (Huber et al. 2009). However, expression of a dominant-negative T $\beta$ RII abrogated this response underlining the importance of TGF- $\beta$ signaling in this process. Activin signaling also shows similarities to TGF- $\beta$ signaling in the suppression of T-cell proliferation and differentiation (Hedger et al. 1989; Semitekolou et al. 2009; Ogawa and Funaba 2011). Treatment of naïve $T$ cells with ac- 
M.W. Pickup et al.

tivin A decreases the induction of proliferation and activation in response to signaling by APCs (Semitekolou et al. 2009). Given the profound synergy between the induction of activin signaling and TGF- $\beta$ signaling in eliciting Treg cell differentiation in $\mathrm{T}$ cells, it would be interesting to test this cooperative effect of TGF- $\beta$ and activin stimulation in the antiproliferative and suppressed activation of $\mathrm{T}$ cells. Treatment of $\mathrm{CD} 4^{+} \mathrm{T}$ cells with dorsomorphin, an antagonist of BMP type I receptors, inhibits proliferation and Th1 differentiation (Yoshioka et al. 2012). Additionally, treatment of $\mathrm{CD} 4^{+}$cells with dorsomorphin prevents the induction of Th17 and Treg cell differentiation (Yoshioka et al. 2012). The significant evidence for a protumorigenic function of TGF- $\beta$ family signaling in T-cell function remains one of the best appreciated aspects of TGF- $\beta$ signaling with a relatively well-defined phenotypic response. Despite this, more studies are needed to provide the correct contextual evidence for disruption of these protumorigenic functions toward efficacious treatments for patients. Given the impact of the adaptive immune system on tumor progression, the TGF- $\beta$ family is an attractive target for therapeutic intervention to enhance antitumoral immune responses.

\section{INNATE IMMUNE-CELL-MEDIATED INFLAMMATION}

In tissue homeostasis, the innate immune response mediates removal of foreign antigens through activation of adaptive immune cell populations. Although complex in function, these cell types act in concert to induce cytotoxic cell death in foreign or abnormal tissue and clear the resulting cellular debris. The cytotoxic cell death induced by CTLs is mediated through numerous secreted factors and direct cell-cell interactions. In the cellular response, there is a notable shift in the activation of innate immune cells from a proimmunogenic phenotype (classical activation) toward a more anti-immunogenic response (alternative activation) (Biswas and Mantovani 2010). This change in activation is indicative of the system as a whole attempting to slow the adaptive immune system and prevent tissue damage and autoimmune disease.

The natural interaction and progression of the immune response can be co-opted by tumors to prevent an antitumorigenic innate immune activation, or classical response, in favor of a protumorigenic, or alternative response. An important signaling system in determining this response is TGF- $\beta$ signaling, which in many cell types has been shown to be critical in alternative activation of innate cellular components (Fig. 3) (Flavell et al. 2010). A well-established example of this is the induction of an M2 phenotype in tumor-associated macrophages. Classical activation of macrophages, induced by interferon $\gamma($ IFN- $\gamma)$ treatment, is associated with promotion of adaptive immune response, particularly the conversion of T cells toward Th1 activation (Mills 2012). Overall, this type of macrophage activation would act to slow tumor progression through antigen presentation and promotion of cytotoxic T-cell function. The alternative activation of macrophages is associated with a gene expression signature that resembles promotion of tissue remodeling and suppression of the adaptive immune system (Murray and Wynn 2011). M2 macrophages secrete TGF- $\beta$ and platelet-derived growth factor (PDGF) to promote stromal fibroblast activation, which in a wound-healing response would correlate with resolution of the wounding response (Qualls and Murray 2011). As mentioned earlier, abrogation of epithelial TGF- $\beta$ signaling leads to recruitment of MDSCs, which inhibit antitumorigenic adaptive immune functions. TGF- $\beta$ signaling in this cell type promotes tumor progression through one of the emerging functional roles of TGF- $\beta$ signaling, the processing of miRNAs. Active TGF- $\beta$ signaling in MDSCs results in increased expression of miR-494 to ultimately enhance the protumorigenic secretion of arginase-1 and MMPs (Liu et al. 2012).

BMP signaling has also been shown to promote macrophages into an alternative activation path through increased expression of IL-6, TNF- $\alpha$, and monocyte chemoattractant protein 1 (MCP-1/CCL2), all of which are associated with an M2 phenotype in macrophages (Rocher et al. 2012). Recent studies into the use 

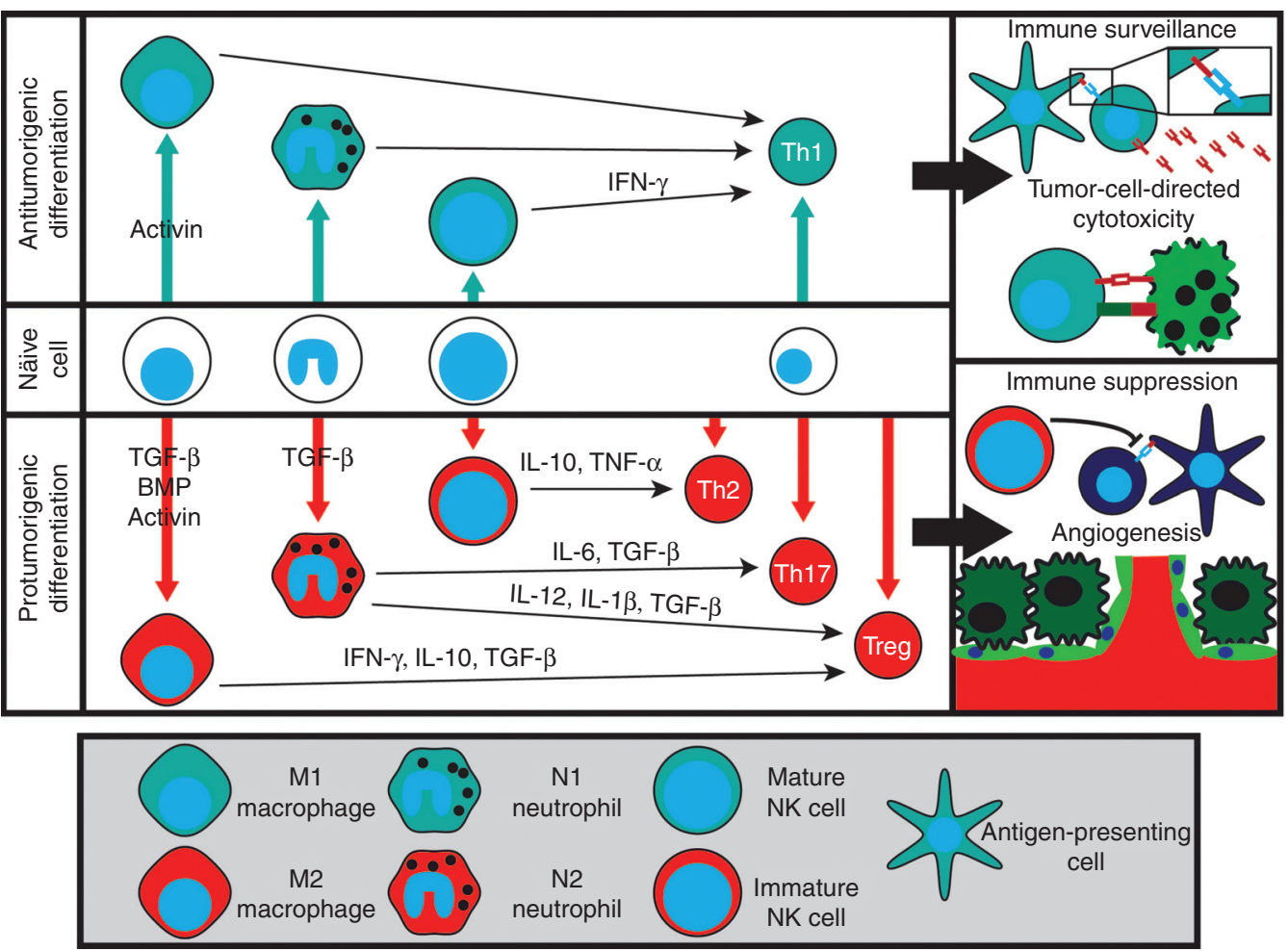

Figure 3. Pro- or antitumorigenic immune functions are driven by transforming growth factor $\beta$ (TGF- $\beta$ ) family signaling modulating immune cell differentiation and function. Numerous cell types in the innate immune system differentiate to a protumorigenic phenotype in response to TGF- $\beta$, bone morphogenetic protein (BMP) or activin signaling. One process through which these protumorigenic cells promote tumor progression is by shifting the adaptive immune system to a protumorigenic phenotype. The protumorigenic differentiation of adaptive immune cells is also driven in part by TGF- $\beta$ family signaling. The end result is the inhibition of immune surveillance and tumor cell directed cytotoxicity and the promotion of Th2 T-cell responses and angiogenesis to promote tumor progression.

of BMP inhibitory drugs has shown that systemic inhibition of BMP signaling leads to an overall increase in immune cells, in particular F4/80 macrophages that are not M2-like but have a tumor suppressive M1-like phenotype (Owens et al. 2014). The role of activin signaling in macrophage activation is not as clear. Studies in mouse macrophages show that activin treatment results in suppression of iNOS and induction of arginase- 1 expression, both of which are associated with an M2 macrophage polarization (Zhang et al. 2005; Ogawa et al. 2006). However, additional evidence indicates high-level activin signaling in association with M1 macrophage differentiation (Sierra-Filardi et al. 2011). Although these results seem contradictory, this discrepancy may be explained by the models used in these studies. Activin signaling could promote resting macrophages toward an M1 activation phenotype, while maintaining an M2 activation state in macrophages that were already activated (Ogawa et al. 2006; Wang et al. 2008b; Zhou et al. 2009; Antsiferova and Werner 2012). As in other signaling contexts discussed, there is also the potential for these differential responses to be mediated by cooperative or competitive signaling between different ligands of the TGF- $\beta$ family. Thus, it would be interesting to determine whether these different responses of macrophages to activin stimulation depend on the context of the other TGF$\beta$ family members. 
M.W. Pickup et al.

Although macrophages are the most abundant cell population of the innate immune system in the tumor microenvironment, other cell types still have a significant effect on tumor progression. Neutrophils can also have differential effects through a similar activation phenotype as the one associated with macrophages. In addition to promoting neutrophil migration, TGF- $\beta$ promotes a protumorigenic differentiation program in neutrophils. In tumor-associated neutrophils (TANs) present in lung cancer, TGF- $\beta$ signaling induces a gene expression program that suppresses T-cell activity and promotes myeloid cell infiltration through increased arginase and CCL5 expression (Fridlender et al. 2009). Similar studies on the functional effects of BMP and activin signaling in neutrophils have not been reported; however, neutrophils may serve as a primary source of activin A in inflammatory responses (Sideras et al. 2013). The effect of the release of this cytokine on tumor progression has yet to be established as pro- or antitumorigenic.

Dendritic cells represent another key cell population in the tumor microenvironment. TGF- $\beta$ suppresses the migration and maturation of dendritic cells, thus slowing tumordirected cytotoxic T-cell activity (Perrot et al. 2007). At an additional level, TGF- $\beta$ has been shown to act on previously matured dendritic cells to promote T-cell differentiation toward a Treg cell path (Kobie et al. 2003), once again stunting T-cell activity directed toward tumor cells.

Other members of the TGF- $\beta$ family do not share this inhibitory effect on dendritic cells. In fact, activin and BMP signaling both oppose TGF- $\beta$ in that they promote dendritic cell migration and maturation and enhance T-cell stimulation (Scutera et al. 2008; Salogni et al. 2009). TGF- $\beta$ family members direct an antitumorigenic immune response. Once the adaptive immune system has been activated, it can remove non-self cells through the activation of phagocytic NK cells. Acting through specific NK cell group 2 receptors (NKG2), NK cells direct targeted killing (Vivier et al. 2012). TGF- $\beta$ inhibits the cytotoxicity of these cells to promote tumorigenesis through decreased expression of NKG2 receptors as well as IFN- $\gamma$ (Allan et al. 2010; Crane et al. 2010). Additionally, the immune suppressive effects of TGF- $\beta$ in NK cells have been associated with a Foxp3 gene expression program, which, much like in Treg cells, inhibits T-cell function, thus stunting potentially antitumorigenic adaptive immune responses (Monteiro et al. 2010). Activin signaling performs similar functions in NK cells, suppressing the expression of inflammatory cytokines such as IFN- $\gamma$, but does not have any significant effect on direct cytotoxicity of these cells. Important to the direct cytotoxic effect of these cells, activin A signaling does not inhibit the expression of NK cell lectin-like receptor subfamily K member 1 (NKG2D), an activating receptor that promotes NK-cell-mediated cell lysis (Robson et al. 2009). Studies into the effects of BMP signaling on NK cells are limited; however, BMP receptors are expressed by NK cells, and BMP signaling is associated with NK cell differentiation in the thymus (Hidalgo et al. 2012). BMP stimulation of NK cells promotes activation and activity through enhanced Th1associated cytokine response (Robson et al. 2014). These limited studies point to an antitumorigenic response of NK cells to BMP stimulation, and further mechanistic studies should reveal whether this pathway is a potential target for therapeutic intervention to enhance chemotherapeutic response.

Although TGF- $\beta$ has an inhibitory effect at all levels of immune regulation, the data for $\mathrm{BMPs}$ are less clear. BMP signaling in T cells and macrophages promote a protumorigenic effect, yet BMP signaling in dendritic cells and NK cells is associated with an antitumorigenic profile. Similarly, activin signaling appears to have diverse immunogenic effects dependent on the cell type to suppress immune function in T cells, macrophages, and NK cells while promoting immune function in dendritic cells. These many contradictory effects by BMP and activin make the systemic results of their signaling in the context of the immune system difficult to discern and confounds the implementation of therapeutic interventions without further investigation of the specific roles of these pathways in the broad scope of cancer-directed immune 
functions. These studies, again, underscore the importance of further work identifying how to efficaciously target these pathways to provide significant patient benefit while avoiding complications from alleviating the antitumorigenic functions of activating these signaling pathways.

\section{CONCLUDING REMARKS}

The TGF- $\beta$ pathways are highly studied and important because of their numerous and essential roles in embryonic development, tissue homeostasis, and disease initiation and progression. However, the successful implementation of therapeutics directed toward the TGF- $\beta$ pathways remains elusive because of the multiple effects of TGF- $\beta$ signaling on numerous cellular compartments. The role of TGF- $\beta$ signaling in the epithelium is already confusing, showing both pro- and antitumorigenic roles in cancer progression, but add in the tumor microenvironment and there are several more factors and outcomes for consideration. The inhibition of the protumorigenic effects of TGF- $\beta$ in one compartment, such as the immune system, may be met with inhibition of antitumorigenic effects in another, such as endothelial cells resulting in no net change in disease progression. Thus, research on the numerous effects of TGF$\beta$ signaling on the diverse cell populations in the microenvironment is critical. As discussed, activation of TGF- $\beta$ signaling as well as BMP and activin signaling results in a variety of stromal changes, which have significant impacts on tumor progression.

For the most part, TGF- $\beta$ signaling is associated with stromal phenotypes that promote cancer growth and dissemination. The stromal phenotypes resulting from activation of BMP and activin signaling are not as clear, with both pro- and antitumorigenic effects not only in different stromal compartments but also in individual drivers of stromal changes. Although the inhibition of BMP signaling has also been associated with disease progression, this is an example of multiple mechanisms resulting in a similar phenotype. For example, in T cells, active TGF- $\beta$, BMP, and activin signaling suppresses the activation of the adaptive immune system through numerous mechanisms. However, targeted inactivation of Smad4 expression, which partially inhibits canonical TGF- $\beta$ family signaling, specifically in $\mathrm{CD} 4^{+}$ $\mathrm{T}$ cells, results in gastrointestinal carcinoma formation, even without introduction of genetic alterations in the epithelial cells (Kim et al. 2006; Cejalvo et al. 2007; Li and Flavell 2008; Aleman-Muench and Soldevila 2012). Thus, although activation signaling by single TGF- $\beta$ family ligands has been associated with an inhibitory response, the shared activity of Smad4 in TGF- $\beta$ family signaling may indicate that these outcomes depend on interactions with other signaling pathways. Such findings underlie the importance of further investigation into these pathways in cancer to determine whether the TGF- $\beta$ family can be therapeutically targeted in a way to benefit patient outcome. It is also important to determine whether these pathways cooperate with or antagonize other signaling pathways that may be identified for therapeutic targeting, such as the NF- $\mathrm{kB}$ pathway (Bitzer et al. 2000; Freudlsperger et al. 2013).

As highlighted in this review, the cooperation among the TGF- $\beta$ family pathways is an important determinant of the phenotypic outcome resulting from individual pathway activation. Although often acting in very distinct ways, TGF- $\beta$, BMP, and activin signaling share many similarities in their intracellular mediators. These overlapping interactions may explain why varying and often opposing phenotypes are obtained from similar experiments investigating phenotypic results of TGF- $\beta$ family activation and could be an important contextual determinant for anticipating consequences of intervention. For example, activin signaling enhances TGF- $\beta$-mediated conversion of Foxp $3^{+}$Treg cells (Huber et al. 2009). Additional studies, particularly in fibroblasts, show pathway antagonism rather than cooperation between the TGF- $\beta$ and BMP pathways. Specifically, disruption of TGF- $\beta$ signaling enhances BMP signaling, whereas BMP signaling suppresses TGF- $\beta$ signaling (Koli et al. 2004).

Individually, activation of each of these signaling pathways in fibroblasts is associated with 
M.W. Pickup et al.

an increase in fibroblast function, such as $\alpha$ SMA expression and collagen deposition. However, preclinical studies with inhibitors of TGF$\beta$ signaling have not shown a specific effect on fibroblast function in mouse models of cancer (Akhurst and Hata 2012). Such data underlie the importance of establishing better preclinical models that allow for a more mechanistic understanding of the signaling complexities within these relevant systems. This includes establishing better markers for cell specification, interactions between clinically relevant oncogenes and microenvironmental components, and a large-scale breakdown of signaling within these cells and the context in which they are studied. It is possible that this is because of compensation by BMP signaling continuing to promote fibroblast activation and function. It would be interesting to determine whether TGF- $\beta$ signaling inhibitors are more or less effective in diseases that are characterized by TGF$\beta$ signaling but also have high levels of BMP and activin signaling. These studies could also reveal additional targets for therapeutic intervention by modulating numerous TGF- $\beta$ family pathways. An example of this could be betaglycan/ T $\beta$ RIII, which much like T $\beta R I I$ has a complex role in cancer progression showing both tumor promoting and suppressing activities (Dong et al. 2007; Criswell et al. 2008). Although betaglycan/T $\beta$ RIII is known for its role in presenting TGF- $\beta 2$ to T $\beta$ RII to activate TGF- $\beta$ signaling, this coreceptor has also been shown to mediate activation of BMP and activin signaling (Cheifetz et al. 1990; Harrison et al. 2004). Thus, targeting of this receptor could antagonize both the TGF- $\beta$ and BMP pathways together to prevent any compensation to obtain a positive therapeutic effect. However, the conceptual framework for the interactions between the TGF- $\beta$, BMP, and activin pathways is a very interesting field of research, in which new findings could finally elucidate effective targeting contexts for the TGF- $\beta$ family as a whole.

Adding to the complexity of the interactions between the TGF- $\beta$ family pathways is the fact that this is all occurring within the context of a heterogeneous cellular tumor microenvironment. Given the significant effects of each sig- naling pathway on the development of stromal phenotypes associated with tumor progression, an understanding of how these pathways mediate stromal changes will be essential to furthering our understanding of the TGF- $\beta$ family's mediation of stromal changes to influence tumor progression.

\section{REFERENCES}

Achyut BR, Bader DA, Robles AI, Wangsa D, Harris CC, Ried T, Yang L. 2013. Inflammation-mediated genetic and epigenetic alterations drive cancer development in the neighboring epithelium upon stromal abrogation of TGF- $\beta$ signaling. PLoS Genet 9: e1003251.

Akhurst RJ, Hata A. 2012. Targeting the TGF- $\beta$ signalling pathway in disease. Nat Rev Drug Discov 11: 790-811.

Akman HO, Zhang H, Siddiqui MA, Solomon W, Smith EL, Batuman OA. 2001. Response to hypoxia involves transforming growth factor- $\beta 2$ and Smad proteins in human endothelial cells. Blood 98: 3324-3331.

Aleman-Muench GR, Soldevila G. 2012. When versatility matters: Activins/inhibins as key regulators of immunity. Immunol Cell Biol 90: 137-148.

Allan DS, Rybalov B, Awong G, Zuniga-Pflucker JC, Kopcow HD, Carlyle JR, Strominger JL. 2010. TGF- $\beta$ affects development and differentiation of human natural killer cell subsets. Eur J Immunol 40: 2289-2295.

Allinson KR, Lee HS, Fruttiger M, McCarty JH, Arthur HM. 2012. Endothelial expression of TGF- $\beta$ type II receptor is required to maintain vascular integrity during postnatal development of the central nervous system. PLoS ONE 7: e39336.

Amendt C, Schirmacher P, Weber H, Blessing M. 1998. Expression of a dominant negative type II TGF- $\beta$ receptor in mouse skin results in an increase in carcinoma incidence and an acceleration of carcinoma development. Oncogene 17: 25-34.

Antsiferova M, Werner S. 2012. The bright and the dark sides of activin in wound healing and cancer. J Cell Sci 125: 3929-3937.

Baker AM, Bird D, Lang G, Cox TR, Erler JT. 2013. Lysyl oxidase enzymatic function increases stiffness to drive colorectal cancer progression through FAK. Oncogene 32: $1863-1868$.

Barry-Hamilton V, Spangler R, Marshall D, McCauley S, Rodriguez HM, Oyasu M, Mikels A, Vaysberg M, Ghermazien H, Wai C, et al. 2010. Allosteric inhibition of lysyl oxidase-like-2 impedes the development of a pathologic microenvironment. Nat Med 16: 1009-1017.

Beavis PA, Stagg J, Darcy PK, Smyth MJ. 2012. CD73: A potent suppressor of antitumor immune responses. Trends Immunol 33: 231-237.

Bein K, Simons M. 2000. Thrombospondin type 1 repeats interact with matrix metalloproteinase 2. Regulation of metalloproteinase activity. J Biol Chem 275: 3216732173.

Bergamaschi A, Tagliabue E, Sorlie T, Naume B, Triulzi T, Orlandi R, Russnes HG, Nesland JM, Tammi R, Auvinen 
P, et al. 2008. Extracellular matrix signature identifies breast cancer subgroups with different clinical outcome. J Pathol 214: 357-367.

Bergers G, Benjamin LE. 2003. Tumorigenesis and the angiogenic switch. Nat Rev Cancer 3: 401-410.

Bhowmick NA, Chytil A, Plieth D, Gorska AE, Dumont N, Shappell S, Washington MK, Neilson EG, Moses HL. 2004. TGF- $\beta$ signaling in fibroblasts modulates the oncogenic potential of adjacent epithelia. Science 303: 848 851.

Bieniasz M, Oszajca K, Eusebio M, Kordiak J, Bartkowiak J, Szemraj J. 2009. The positive correlation between gene expression of the two angiogenic factors: VEGF and BMP-2 in lung cancer patients. Lung Cancer 66: 319326.

Bierie B, Moses HL. 2006. TGFß: The molecular Jekyll and Hyde of cancer. Nat Rev Cancer 6: 506-520.

Bierie B, Stover DG, Abel TW, Chytil A, Gorska AE, Aakre M, Forrester E, Yang L, Wagner KU, Moses HL. 2008. Transforming growth factor- $\beta$ regulates mammary carcinoma cell survival and interaction with the adjacent microenvironment. Cancer Res 68: 1809-1819.

Bierie B, Chung CH, Parker JS, Stover DG, Cheng N, Chyti A, Aakre M, Shyr Y, Moses HL. 2009. Abrogation of TGF$\beta$ signaling enhances chemokine production and correlates with prognosis in human breast cancer. J Clin Invest 119: $1571-1582$.

Biswas SK, Mantovani A. 2010. Macrophage plasticity and interaction with lymphocyte subsets: Cancer as a paradigm. Nat Immunol 11: 889-896.

Bitzer M, von Gersdorff G, Liang D, Dominguez-Rosales A, Beg AA, Rojkind M, Bottinger EP. 2000. A mechanism of suppression of TGF- $\beta /$ SMAD signaling by NF- $\mathrm{B} /$ RelA Genes Dev 14: 187-197.

Boak AM, Roy R, Berk J, Taylor L, Polgar P, Goldstein RH, Kagan HM. 1994. Regulation of lysyl oxidase expression in lung fibroblasts by transforming growth factor- $\beta 1$ and prostaglandin E2. Am J Respir Cell Mol Biol 11: 751-755.

Bommireddy R, Pathak LJ, Martin J, Ormsby I, Engle SJ, Boivin GP, Babcock GF, Eriksson AU, Singh RR, Doetschman T. 2006. Self-antigen recognition by TGF $\beta 1$-deficient $\mathrm{T}$ cells causes their activation and systemic inflammation. Lab Invest 86: 1008-1019.

Border WA, Noble NA. 1994. Transforming growth factor $\beta$ in tissue fibrosis. N Engl J Med 331: 1286-1292.

Boyd NF, Guo H, Martin LJ, Sun L, Stone J, Fishell E, Jong RA, Hislop G, Chiarelli A, Minkin S, et al. 2007. Mammographic density and the risk and detection of breast cancer. N Engl J Med 356: 227-236.

Busch S, Acar A, Magnusson Y, Gregersson P, Ryden L, Landberg G. 2015. TGF- $\beta$ receptor type-2 expression in cancer-associated fibroblasts regulates breast cancer cell growth and survival and is a prognostic marker in premenopausal breast cancer. Oncogene 34: 27-38.

Byrne SN, Knox MC, Halliday GM. 2008. TGF- $\beta$ is responsible for skin tumour infiltration by macrophages enabling the tumours to escape immune destruction. Immunol Cell Biol 86: 92-97.

Calon A, Espinet E, Palomo-Ponce S, Tauriello DV, Iglesias M, Cespedes MV, Sevillano M, Nadal C, Jung P, Zhang XH, et al. 2012. Dependency of colorectal cancer on a
TGF- $\beta$ Signaling in the Tumor Microenvironment

TGF- $\beta$-driven program in stromal cells for metastasis initiation. Cancer Cell 22: 571-584.

Cejalvo T, Sacedon R, Hernandez-Lopez C, Diez B, Gutierrez-Frias C, Valencia J, Zapata AG, Varas A, Vicente A. 2007. Bone morphogenetic protein-2/4 signalling pathway components are expressed in the human thymus and inhibit early T-cell development. Immunology 121: 94104.

Chalmin F, Mignot G, Bruchard M, Chevriaux A, Vegran F, Hichami A, Ladoire S, Derangere V, Vincent J, Masson D, et al. 2012. Stat3 and Gfi-1 transcription factors control Th17 cell immunosuppressive activity via the regulation of ectonucleotidase expression. Immunity 36: 362-373.

Chambers RC, Leoni P, Kaminski N, Laurent GJ, Heller RA. 2003. Global expression profiling of fibroblast responses to transforming growth factor- $\beta 1$ reveals the induction of inhibitor of differentiation-1 and provides evidence of smooth muscle cell phenotypic switching. Am J Pathol 162: $533-546$.

Chang H, Huylebroeck D, Verschueren K, Guo Q, Matzuk MM, Zwijsen A. 1999. Smad5 knockout mice die at midgestation due to multiple embryonic and extraembryonic defects. Development 126: 1631-1642.

Cheifetz S, Hernandez H, Laiho M, ten Dijke P, Iwata KK, Massague J. 1990. Distinct transforming growth factor $\beta$ (TGF- $\beta$ ) receptor subsets as determinants of cellular responsiveness to three TGF- $\beta$ isoforms. J Biol Chem 265: 20533-20538.

Chen W, Jin W, Hardegen N, Lei KJ, Li L, Marinos N, McGrady G, Wahl SM. 2003. Conversion of peripheral $\mathrm{CD} 4{ }^{+} \mathrm{CD} 25^{-}$naive $\mathrm{T}$ cells to $\mathrm{CD} 4{ }^{+} \mathrm{CD} 25^{+}$regulatory $\mathrm{T}$ cells by TGF- $\beta$ induction of transcription factor Foxp3. J Exp Med 198: 1875-1886.

Crane CA, Han SJ, Barry JJ, Ahn BJ, Lanier LL, Parsa AT. 2010. TGF- $\beta$ downregulates the activating receptor NKG2D on NK cells and $\mathrm{CD} 8^{+} \mathrm{T}$ cells in glioma patients. Neuro Oncol 12: 7-13.

Criswell TL, Dumont N, Barnett JV, Arteaga CL. 2008. Knockdown of the transforming growth factor- $\beta$ type III receptor impairs motility and invasion of metastatic cancer cells. Cancer Res 68: 7304-7312.

Dang D, Yang Y, Li X, Atakilit A, Regezi J, Eisele D, Ellis D, Ramos DM. 2004. Matrix metalloproteinases and TGF $\beta 1$ modulate oral tumor cell matrix. Biochem Biophys Res Commun 316: 937-942.

David L, Mallet C, Mazerbourg S, Feige JJ, Bailly S. 2007. Identification of BMP9 and BMP10 as functional activators of the orphan activin receptor-like kinase 1 (ALK1) in endothelial cells. Blood 109: 1953-1961.

Davis BN, Hilyard AC, Lagna G, Hata A. 2008. SMAD proteins control DROSHA-mediated microRNA maturation. Nature 454: 56-61.

Desmouliere A, Geinoz A, Gabbiani F, Gabbiani G. 1993. Transforming growth factor- $\beta 1$ induces $\alpha$-smooth muscle actin expression in granulation tissue myofibroblast and in quiescent and growing cultured fibroblasts. J Cell Biol 122: 103-111.

Diebold RJ, Eis MJ, Yin M, Ormsby I, Boivin GP, Darrow BJ, Saffitz JE, Doetschman T. 1995. Early-onset multifocal inflammation in the transforming growth factor $\beta 1$ null mouse is lymphocyte mediated. Proc Natl Acad Sci 92: $12215-12219$. 
M.W. Pickup et al.

Dong M, How T, Kirkbride KC, Gordon KJ, Lee JD, Hempe N, Kelly P, Moeller BJ, Marks JR, Blobe GC. 2007. The type III TGF- $\beta$ receptor suppresses breast cancer progression. J Clin Invest 117: 206-217.

Duitman J, Borensztajn KS, Pulskens WP, Leemans JC, Florquin S, Spek CA. 2014. CCAAT-enhancer binding protein delta (C/EBP $\delta)$ attenuates tubular injury and tubulointerstitial fibrogenesis during chronic obstructive nephropathy. Lab Invest 94: 89-97.

Dumont N, Liu B, Defilippis RA, Chang H, Rabban JT, Karnezis AN, Tjoe JA, Marx J, Parvin B, Tlsty TD. 2013 Breast fibroblasts modulate early dissemination, tumorigenesis, and metastasis through alteration of extracellular matrix characteristics. Neoplasia 15: 249-262.

Ellis LM. 2006. The role of neuropilins in cancer. Mol Cancer Ther 5: 1099-1107.

Erler JT, Bennewith KL, Nicolau M, Dornhofer N, Kong C, Le QT, Chi JT, Jeffrey SS, Giaccia AJ. 2006. Lysyl oxidase is essential for hypoxia-induced metastasis. Nature 440: 1222-1226.

Falanga V, Qian SW, Danielpour D, Katz MH, Roberts AB, Sporn MB. 1991. Hypoxia upregulates the synthesis of TGF- $\beta 1$ by human dermal fibroblasts. J Invest Dermato 97: 634-637.

Ferrara N, Hillan KJ, Gerber HP, Novotny W. 2004. Discovery and development of bevacizumab, an anti-VEGF antibody for treating cancer. Nat Rev Drug Discov 3: 391400.

Fessing MY, Atoyan R, Shander B, Mardaryev AN, Botchkarev VV Jr, Poterlowicz K, Peng Y, Efimova T, Botchkarev VA. 2010. BMP signaling induces cell-type-specific changes in gene expression programs of human keratinocytes and fibroblasts. J Invest Dermatol 130: 398-404.

Filippi CM, Juedes AE, Oldham JE, Ling E, Togher L, Peng Y, Flavell RA, von Herrath MG. 2008. Transforming growth factor- $\beta$ suppresses the activation of $\mathrm{CD} 8^{+} \mathrm{T}$-cells when naive but promotes their survival and function once antigen experienced: A two-faced impact on autoimmunity. Diabetes 57: 2684-2692.

Finak G, Bertos N, Pepin F, Sadekova S, Souleimanova M, Zhao H, Chen H, Omeroglu G, Meterissian S, Omeroglu A, et al. 2008. Stromal gene expression predicts clinical outcome in breast cancer. Nat Med 14: 518-527.

Flavell RA, Sanjabi S, Wrzesinski SH, Licona-Limon P. 2010. The polarization of immune cells in the tumour environment by TGF $\beta$. Nat Rev Immunol 10: 554-567.

Fordyce CA, Patten KT, Fessenden TB, DeFilippis R, Hwang ES, Zhao J, Tlsty TD. 2012. Cell-extrinsic consequences of epithelial stress: Activation of protumorigenic tissue phenotypes. Breast Cancer Res 14: R155.

Franses JW, Baker AB, Chitalia VC, Edelman ER. 2011. Stromal endothelial cells directly influence cancer progression. Sci Transl Med 3: 66ra65.

Freudlsperger C, Bian Y, Contag Wise S, Burnett J, Coupar J, Yang X, Chen Z, Van Waes C. 2013. TGF- $\beta$ and NF-кB signal pathway cross-talk is mediated through TAK1 and SMAD7 in a subset of head and neck cancers. Oncogene 32: $1549-1559$.

Fridlender ZG, Sun J, Kim S, Kapoor V, Cheng G, Ling L, Worthen GS, Albelda SM. 2009. Polarization of tumorassociated neutrophil phenotype by TGF- $\beta$ : "N 1 " versus "N2" TAN. Cancer Cell 16: 183-194.
Fumagalli M, Musso T, Vermi W, Scutera S, Daniele R, Alotto D, Cambieri I, Ostorero A, Gentili F, Caposio P, et al. 2007. Imbalance between activin A and follistatin drives postburn hypertrophic scar formation in human skin. Exp Dermatol 16: 600-610.

Geng L, Chaudhuri A, Talmon G, Wisecarver JL, Wang J. 2013. TGF- $\beta$ suppresses VEGFA-mediated angiogenesis in colon cancer metastasis. PLoS ONE 8: e59918.

Germain RN. 2002. T-cell development and the CD4-CD8 lineage decision. Nat Rev Immunol 2: 309-322.

Gorelik L, Flavell RA. 2000. Abrogation of TGF $\beta$ signaling in $\mathrm{T}$ cells leads to spontaneous $\mathrm{T}$ cell differentiation and autoimmune disease. Immunity 12: 171-181.

Guillot N, Kollins D, Gilbert V, Xavier S, Chen J, Gentle M, Reddy A, Bottinger E, Jiang R, Rastaldi MP, et al. 2012. BAMBI regulates angiogenesis and endothelial homeostasis through modulation of alternative TGF $\beta$ signaling. PLOS ONE 7: e39406.

Gunturi A, Berg RE, Crossley E, Murray S, Forman J. 2005. The role of TCR stimulation and TGF- $\beta$ in controlling the expression of CD94/NKG2A receptors on CD8 T cells. Eur J Immunol 35: 766-775.

Hanahan D, Coussens LM. 2012. Accessories to the crime: Functions of cells recruited to the tumor microenvironment. Cancer Cell 21: 309-322.

Hanahan D, Weinberg RA. 2000. The hallmarks of cancer. Cell 100: 57-70.

Hardwick JC, Kodach LL, Offerhaus GJ, van den Brink GR. 2008. Bone morphogenetic protein signalling in colorectal cancer. Nat Rev Cancer 8: 806-812.

Harrison CA, Wiater E, Gray PC, Greenwald J, Choe S, Vale W. 2004. Modulation of activin and BMP signaling. Mol Cell Endocrinol 225: 19-24.

Hawinkels LJ, Kuiper P, Wiercinska E, Verspaget HW, Liu Z, Pardali E, Sier CF, ten Dijke P. 2010. Matrix metalloproteinase-14 (MT1-MMP)-mediated endoglin shedding inhibits tumor angiogenesis. Cancer Res 70: 4141-4150.

Hazelbag S, Gorter A, Kenter GG, van den Broek L, Fleuren G. 2002. Transforming growth factor- $\beta 1$ induces tumor stroma and reduces tumor infiltrate in cervical cancer. Hum Pathol 33: 1193-1199.

Hedger MP, Drummond AE, Robertson DM, Risbridger GP, de Kretser DM. 1989. Inhibin and activin regulate $\left[{ }^{3} \mathrm{H}\right]$ thymidine uptake by rat thymocytes and $3 \mathrm{~T} 3$ cells in vitro. Mol Cell Endocrinol 61: 133-138.

Hida K, Hida Y, Shindoh M. 2008. Understanding tumor endothelial cell abnormalities to develop ideal anti-angiogenic therapies. Cancer Sci 99: 459-466.

Hidalgo L, Martinez VG, Valencia J, Hernandez-Lopez C, Vazquez MN, Nunez JR, Zapata AG, Sacedon R, Varas A, Vicente A. 2012. Expression of BMPRIA on human thymic NK cell precursors: Role of BMP signaling in intrathymic NK cell development. Blood 119: 1861-1871.

Huber S, Stahl FR, Schrader J, Luth S, Presser K, Carambia A, Flavell RA, Werner S, Blessing M, Herkel J, et al. 2009. Activin a promotes the TGF- $\beta$-induced conversion of $\mathrm{CD} 4^{+} \mathrm{CD} 25^{-} \mathrm{T}$ cells into Foxp $3^{+}$induced regulatory $\mathrm{T}$ cells. J Immunol 182: 4633-4640.

Inman GJ, Nicolas FJ, Callahan JF, Harling JD, Gaster LM, Reith AD, Laping NJ, Hill CS. 2002. SB-431542 is a potent and specific inhibitor of transforming growth factor- $\beta$ 
superfamily type I activin receptor-like kinase (ALK) receptors ALK4, ALK5, and ALK7. Mol Pharmacol 62: 6574 .

Izumi N, Mizuguchi S, Inagaki Y, Saika S, Kawada N, Nakajima Y, Inoue K, Suehiro S, Friedman SL, Ikeda K. 2006. BMP-7 opposes TGF- $\beta 1$-mediated collagen induction in mouse pulmonary myofibroblasts through Id2. Am J Physiol Lung Cell Mol Physiol 290: L120-L126.

Jinka R, Kapoor R, Sistla PG, Raj TA, Pande G. 2012. Alterations in cell-extracellular matrix interactions during progression of cancers. Int J Cell Biol 2012: 219196.

Kalluri R, Zeisberg M. 2006. Fibroblasts in cancer. Nat Rev Cancer 6: 392-401.

Karin N. 2010. The multiple faces of CXCL12 (SDF-1 $\alpha)$ in the regulation of immunity during health and disease. J Leukoc Biol 88: 463-473.

Karlsson G, Blank U, Moody JL, Ehinger M, Singbrant S, Deng CX, Karlsson S. 2007. Smad4 is critical for selfrenewal of hematopoietic stem cells. J Exp Med 204: 467-474.

Kim BG, Li C, Qiao W, Mamura M, Kasprzak B, Anver M, Wolfraim L, Hong S, Mushinski E, Potter M, et al. 2006. Smad4 signalling in T cells is required for suppression of gastrointestinal cancer. Nature 441: 1015-1019.

Kobie JJ, Wu RS, Kurt RA, Lou S, Adelman MK, Whitesell LJ, Ramanathapuram LV, Arteaga CL, Akporiaye ET. 2003. Transforming growth factor $\beta$ inhibits the antigen-presenting functions and antitumor activity of dendritic cell vaccines. Cancer Res 63: 1860-1864.

Kojc N, Zidar N, Vodopivec B, Gale N. 2005. Expression of CD34, $\alpha$-smooth muscle actin, and transforming growth factor $\beta 1$ in squamous intraepithelial lesions and squamous cell carcinoma of the larynx and hypopharynx. Hum Pathol 36: 16-21.

Koli K, Wempe F, Sterner-Kock A, Kantola A, Komor M, Hofmann WK, von Melchner H, Keski-Oja J. 2004. Disruption of LTBP-4 function reduces TGF- $\beta$ activation and enhances BMP-4 signaling in the lung. $J$ Cell Biol 167: $123-133$.

Kulkarni AB, Huh CG, Becker D, Geiser A, Lyght M, Flanders KC, Roberts AB, Sporn MB, Ward JM, Karlsson S. 1993. Transforming growth factor $\beta 1$ null mutation in mice causes excessive inflammatory response and early death. Proc Natl Acad Sci 90: 770-774.

Kuperwasser C, Chavarria T, Wu M, Magrane G, Gray JW, Carey L, Richardson A, Weinberg RA. 2004. Reconstruction of functionally normal and malignant human breast tissues in mice. Proc Natl Acad Sci 101: 4966-4971.

Lan Y, Liu B, Yao H, Li F, Weng T, Yang G, Li W, Cheng X, Mao N, Yang X. 2007. Essential role of endothelial Smad4 in vascular remodeling and integrity. Mol Cell Biol 27: $7683-7692$.

Langenfeld EM, Langenfeld J. 2004. Bone morphogenetic protein-2 stimulates angiogenesis in developing tumors. Mol Cancer Res 2: 141-149.

Lebrin F, Deckers M, Bertolino P, Ten Dijke P. 2005. TGF- $\beta$ receptor function in the endothelium. Cardiovasc Res 65: 599-608.

Leight JL, Wozniak MA, Chen S, Lynch ML, Chen CS. 2012. Matrix rigidity regulates a switch between TGF- $\beta 1$-in- duced apoptosis and epithelial-mesenchymal transition. Mol Biol Cell 23: 781-791.

Levental KR, Yu H, Kass L, Lakins JN, Egeblad M, Erler JT, Fong SF, Csiszar K, Giaccia A, Weninger W, et al. 2009. Matrix crosslinking forces tumor progression by enhancing integrin signaling. Cell 139: 891-906.

Li MO, Flavell RA. 2008. TGF- $\beta$ : A master of all T cell trades. Cell 134: 392-404.

Li MO, Wan YY, Flavell RA. 2007. T cell-produced transforming growth factor- $\beta 1$ controls $\mathrm{T}$ cell tolerance and regulates Th1- and Th17-cell differentiation. Immunity 26: $579-591$.

Lijnen P, Petrov V. 2002. Transforming growth factor- $\beta 1$ induced collagen production in cultures of cardiac fibroblasts is the result of the appearance of myofibroblasts. Methods Find Exp Clin Pharmacol 24: 333-344.

Liu D, Wang J, Kinzel B, Mueller M, Mao X, Valdez R, Liu Y, Li E. 2007. Dosage-dependent requirement of BMP type II receptor for maintenance of vascular integrity. Blood 110: $1502-1510$.

Liu Y, Lai L, Chen Q, Song Y, Xu S, Ma F, Wang X, Wang J, Yu $\mathrm{H}$, Cao X, et al. 2012. MicroRNA-494 is required for the accumulation and functions of tumor-expanded myeloid-derived suppressor cells via targeting of PTEN. J Immunol 188: 5500-5510.

Lu P, Weaver VM, Werb Z. 2012. The extracellular matrix: A dynamic niche in cancer progression. J Cell Biol 196: 395-406.

Lucas PJ, Kim SJ, Melby SJ, Gress RE. 2000. Disruption of T cell homeostasis in mice expressing a T cell-specific dominant negative transforming growth factor $\beta$ II receptor. J Exp Med 191: 1187-1196.

Ma XJ, Dahiya S, Richardson E, Erlander M, Sgroi DC. 2009. Gene expression profiling of the tumor microenvironment during breast cancer progression. Breast Cancer Res 11: R7.

Maegdefrau U, Amann T, Winklmeier A, Braig S, Schubert T, Weiss TS, Schardt K, Warnecke C, Hellerbrand C, Bosserhoff AK. 2009. Bone morphogenetic protein 4 is induced in hepatocellular carcinoma by hypoxia and promotes tumour progression. J Pathol 218: 520-529.

Mangan PR, Harrington LE, O'Quinn DB, Helms WS, Bullard DC, Elson CO, Hatton RD, Wahl SM, Schoeb TR, Weaver CT. 2006. Transforming growth factor- $\beta$ induces development of the $\mathrm{T}_{\mathrm{H}} 17$ lineage. Nature 441: 231-234.

Martinez VG, Hernandez-Lopez C, Valencia J, Hidalgo L, Entrena A, Zapata AG, Vicente A, Sacedon R, Varas A. 2011. The canonical BMP signaling pathway is involved in human monocyte-derived dendritic cell maturation. Immunol Cell Biol 89: 610-618.

Martinez VG, Hidalgo L, Valencia J, Hernandez-Lopez C, Entrena A, del Amo BG, Zapata AG, Vicente A, Sacedon R, Varas A. 2014. Autocrine activation of canonical BMP signaling regulates PD-L1 and PD-L2 expression in human dendritic cells. Eur J Immunol 44: 1031-1038.

Martinez-Ferrer M, Afshar-Sherif AR, Uwamariya C, de Crombrugghe B, Davidson JM, Bhowmick NA. 2010. Dermal transforming growth factor- $\beta$ responsiveness mediates wound contraction and epithelial closure. Am J Pathol 176: 98-107.

Massagué J. 2008. TGF $\beta$ in cancer. Cell 134: 215-230. 
M.W. Pickup et al.

Mazzocca A, Fransvea E, Lavezzari G, Antonaci S, Giannell G. 2009. Inhibition of transforming growth factor $\beta$ receptor I kinase blocks hepatocellular carcinoma growth through neo-angiogenesis regulation. Hepatology 50: $1140-1151$.

McCarthy SA, Bicknell R. 1993. Inhibition of vascular endothelial cell growth by activin-A. J Biol Chem 268: 23066-23071.

Mills CD. 2012. M1 and M2 macrophages: Oracles of health and disease. Crit Rev Immunol 32: 463-488.

Min S, Li L, Zhang M, Zhang Y, Liang X, Xie Y, He Q, Li Y, Sun J, Liu Q, et al. 2012. TGF- $\beta$-associated miR-27a inhibits dendritic cell-mediated differentiation of Th1 and Th17 cells by TAB3, p38 MAPK, MAP2K4 and MAP2K7. Genes Immun 13: 621-631.

Monteiro M, Almeida CF, Caridade M, Ribot JC, Duarte J, Agua-Doce A, Wollenberg I, Silva-Santos B, Graca L. 2010. Identification of regulatory Foxp $3^{+}$invariant NKT cells induced by TGF- $\beta$. J Immunol 185: $2157-$ 2163.

Mukhopadhyay A, Chan SY, Lim IJ, Phillips DJ, Phan TT. 2007. The role of the activin system in keloid pathogenesis. Am J Physiol Cell Physiol 292: C1331-C1338.

Muraoka-Cook RS, Shin I, Yi JY, Easterly E, Barcellos-Hoff MH, Yingling JM, Zent R, Arteaga CL. 2006. Activated type I TGF $\beta$ receptor kinase enhances the survival of mammary epithelial cells and accelerates tumor progression. Oncogene 25: 3408-3423.

Murray PJ, Wynn TA. 2011. Protective and pathogenic functions of macrophage subsets. Nat Rev Immunol 11: 723 737.

Murray GI, Duncan ME, O’Neil P, Melvin WT, Fothergill JE. 1996. Matrix metalloproteinase- 1 is associated with poor prognosis in colorectal cancer. Nat Med 2: 461-462.

Nakagawa T, Li JH, Garcia G, Mu W, Piek E, Bottinger EP, Chen Y, Zhu HJ, Kang DH, Schreiner GF, et al. 2004. TGF$\beta$ induces proangiogenic and antiangiogenic factors via parallel but distinct Smad pathways. Kidney Int 66: 605613.

Novitskiy SV, Pickup MW, Chytil A, Polosukhina D, Owens P, Moses HL. 2012. Deletion of TGF- $\beta$ signaling in myeloid cells enhances their anti-tumorigenic properties. J Leukoc Biol 92: 641-651.

Ogawa K, Funaba M. 2011. Activin in humoral immune responses. Vitam Horm 85: 235-253.

Ogawa K, Funaba M, Chen Y, Tsujimoto M. 2006. Activin A functions as a Th2 cytokine in the promotion of the alternative activation of macrophages. J Immunol 177: 6787-6794.

Okochi-Takada E, Hattori N, Tsukamoto T, Miyamoto K, Ando T, Ito S, Yamamura Y, Wakabayashi M, Nobeyama Y, Ushijima T. 2014. ANGPTL4 is a secreted tumor suppressor that inhibits angiogenesis. Oncogene 33: $2273-$ 2278.

Oleinika K, Nibbs RJ, Graham GJ, Fraser AR. 2013. Suppression, subversion and escape: The role of regulatory T cells in cancer progression. Clin Exp Immunol 171: 36-45.

Oshima M, Oshima H, Taketo MM. 1996. TGF- $\beta$ receptor type II deficiency results in defects of yolk sac hematopoiesis and vasculogenesis. Dev Biol 179: 297-302.
Owens P, Pickup MW, Novitskiy SV, Chytil A, Gorska AE, Aakre ME, West J, Moses HL. 2012. Disruption of bone morphogenetic protein receptor 2 (BMPR2) in mammary tumors promotes metastases through cell autonomous and paracrine mediators. Proc Natl Acad Sci 109: 28142819.

Owens P, Polikowsky H, Pickup MW, Gorska AE, Jovanovic B, Shaw AK, Novitskiy SV, Hong CC, Moses HL. 2013. Bone Morphogenetic Proteins stimulate mammary fibroblasts to promote mammary carcinoma cell invasion. PLOS ONE 8: e67533.

Owens P, Pickup MW, Novitskiy SV, Giltnane JM, Gorska AE, Hopkins CR, Hong CC, Moses HL. 2014. Inhibition of BMP signaling suppresses metastasis in mammary cancer. Oncogene 34: 2437-2449.

Paiva CE, Serrano SV, Paiva BS, Scapulatempo-Neto C, Soares FA, Rogatto SR, Marques ME. 2012. Absence of TGF- $\beta$ RII predicts bone and lung metastasis and is associated with poor prognosis in stage III breast tumors. Cancer Biomark 11: 209-217.

Palucka K, Banchereau J. 2012. Cancer immunotherapy via dendritic cells. Nat Rev Cancer 12: 265-277.

Panopoulou E, Murphy C, Rasmussen H, Bagli E, Rofstad EK, Fotsis T. 2005. Activin A suppresses neuroblastoma xenograft tumor growth via antimitotic and antiangiogenic mechanisms. Cancer Res 65: 1877-1886.

Pardali E, ten Dijke P. 2009. Transforming growth factor- $\beta$ signaling and tumor angiogenesis. Front Biosci (Landmark Ed) 14: 4848-4861.

Pardali E, Goumans MJ, ten Dijke P. 2010. Signaling by members of the TGF- $\beta$ family in vascular morphogenesis and disease. Trends Cell Biol 20: 556-567.

Paszek MJ, Zahir N, Johnson KR, Lakins JN, Rozenberg GI, Gefen A, Reinhart-King CA, Margulies SS, Dembo M, Boettiger D, et al. 2005. Tensional homeostasis and the malignant phenotype. Cancer Cell 8: 241-254.

Payne SL, Hendrix MJ, Kirschmann DA. 2007. Paradoxical roles for lysyl oxidases in cancer-A prospect. J Cell Biochem 101: 1338-1354.

Pepper MS. 1997. Transforming growth factor- $\beta$ : Vasculogenesis, angiogenesis, and vessel wall integrity. Cytokine Growth Factor Rev 8: 21-43.

Perrot I, Blanchard D, Freymond N, Isaac S, Guibert B, Pacheco Y, Lebecque S. 2007. Dendritic cells infiltrating human non-small cell lung cancer are blocked at immature stage. J Immunol 178: 2763-2769.

Pickup M, Novitskiy S, Moses HL. 2013a. The roles of TGF $\beta$ in the tumour microenvironment. Nat Rev Cancer 13: 788-799.

Pickup MW, Laklai H, Acerbi I, Owens P, Gorska AE, Chytil A, Aakre M, Weaver VM, Moses HL. 2013b. Stromally derived lysyl oxidase promotes metastasis of transforming growth factor- $\beta$ deficient mouse mammary carcinoma. Cancer Res 73: 5336-5346.

Pickup MW, Hover LD, Polikowsky ER, Chytil A, Gorska AE, Novitskiy SV, Moses HL, Owens P. 2015. BMPR2 loss in fibroblasts promotes mammary carcinoma metastasis via increased inflammation. Mol Oncol 9: 179-191.

Pinto M, Oliveira C, Cirnes L, Carlos Machado J, Ramires M, Nogueira A, Carneiro F, Seruca R. 2003. Promoter methylation of TGF $\beta$ receptor I and mutation of TGF $\beta$ 
receptor II are frequent events in MSI sporadic gastric carcinomas. J Pathol 200: 32-38.

Place AE, Jin Huh S, Polyak K. 2011. The microenvironment in breast cancer progression: biology and implications for treatment. Breast Cancer Res 13: 227.

Provenzano PP, Eliceiri KW, Campbell JM, Inman DR, White JG, Keely PJ. 2006. Collagen reorganization at the tumor-stromal interface facilitates local invasion. BMC Med 4: 38 .

Provenzano PP, Inman DR, Eliceiri KW, Knittel JG, Yan L, Rueden CT, White JG, Keely PJ. 2008. Collagen density promotes mammary tumor initiation and progression. BMC Med 6: 11 .

Qualls JE, Murray PJ. 2011. Tumor macrophages protective and pathogenic roles in cancer development. Curr Top Dev Biol 94: 309-328.

Raida M, Clement JH, Leek RD, Ameri K, Bicknell R, Niederwieser D, Harris AL. 2005. Bone morphogenetic protein 2 (BMP-2) and induction of tumor angiogenesis. $J$ Cancer Res Clin Oncol 131: 741-750.

Reed MJ, Vernon RB, Abrass IB, Sage EH. 1994. TGF- $\beta 1$ induces the expression of type I collagen and SPARC, and enhances contraction of collagen gels, by fibroblasts from young and aged donors. J Cell Physiol 158: 169-179.

Robson NC, Wei H, McAlpine T, Kirkpatrick N, Cebon J, Maraskovsky E. 2009. Activin-A attenuates several human natural killer cell functions. Blood 113: 3218-3225.

Robson NC, Hidalgo L, McAlpine T, Wei H, Martinez VG, Entrena A, Melen GJ, MacDonald AS, Phythian-Adams A, Sacedon R, et al. 2014. Optimal effector functions in human natural killer cells rely upon autocrine bone morphogenetic protein signaling. Cancer Res 74: 5019-5031.

Rocher C, Singla R, Singal PK, Parthasarathy S, Singla DK. 2012. Bone morphogenetic protein 7 polarizes THP-1 cells into M2 macrophages. Can J Physiol Pharmacol 90: 947-951.

Roepman P, Wessels LF, Kettelarij N, Kemmeren P, Miles AJ, Lijnzaad P, Tilanus MG, Koole R, Hordijk GJ, van der Vliet PC, et al. 2005. An expression profile for diagnosis of lymph node metastases from primary head and neck squamous cell carcinomas. Nat Genet 37: 182-186.

Roman-Perez E, Casbas-Hernandez P, Pirone JR, Rein J, Carey LA, Lubet RA, Mani SA, Amos KD, Troester MA. 2012. Gene expression in extratumoral microenvironment predicts clinical outcome in breast cancer patients. Breast Cancer Res 14: R51.

Safina A, Vandette E, Bakin AV. 2007. ALK5 promotes tumor angiogenesis by upregulating matrix metalloproteinase- 9 in tumor cells. Oncogene 26: 2407-2422.

Salogni L, Musso T, Bosisio D, Mirolo M, Jala VR, Haribabu B, Locati M, Sozzani S. 2009. Activin A induces dendritic cell migration through the polarized release of CXC chemokine ligands 12 and 14. Blood 113: 5848-5856.

Sartor MA, Mahavisno V, Keshamouni VG, Cavalcoli J, Wright Z, Karnovsky A, Kuick R, Jagadish HV, Mirel B, Weymouth T, et al. 2010. ConceptGen: A gene set enrichment and gene set relation mapping tool. Bioinformatics 26: $456-463$.

Scherz-Shouval R, Santagata S, Mendillo ML, Sholl LM, Ben-Aharon I, Beck AH, Dias-Santagata D, Koeva M, Stemmer SM, Whitesell L, et al. 2014. The reprogram-
TGF- $\beta$ Signaling in the Tumor Microenvironment

ming of tumor stroma by HSF1 is a potent enabler of malignancy. Cell 158: 564-578.

Scutera S, Riboldi E, Daniele R, Elia AR, Fraone T, Castagnoli C, Giovarelli M, Musso T, Sozzani S. 2008. Production and function of activin A in human dendritic cells. Eur Cytokine Netw 19: 60-68.

Semitekolou M, Alissafi T, Aggelakopoulou M, Kourepini E, Kariyawasam HH, Kay AB, Robinson DS, Lloyd CM, Panoutsakopoulou V, Xanthou G. 2009. Activin-A induces regulatory $\mathrm{T}$ cells that suppress $\mathrm{T}$ helper cell immune responses and protect from allergic airway disease. J Exp Med 206: 1769-1785.

Sideras P, Apostolou E, Stavropoulos A, Sountoulidis A, Gavriil A, Apostolidou A, Andreakos E. 2013. Activin, neutrophils, and inflammation: Just coincidence? Semin Immunopathol 35: 481-499.

Sierra-Filardi E, Puig-Kroger A, Blanco FJ, Nieto C, Bragado R, Palomero MI, Bernabeu C, Vega MA, Corbi AL. 2011. Activin A skews macrophage polarization by promoting a proinflammatory phenotype and inhibiting the acquisition of anti-inflammatory macrophage markers. Blood 117: 5092-5101.

Simantov R, Silverstein RL. 2003. CD36: A critical anti-angiogenic receptor. Front Biosci 8: s874-882.

Sozzani S, Musso T. 2011. The yin and yang of Activin A. Blood 117: 5013-5015.

Steg AD, Katre AA, Goodman B, Han HD, Nick AM, Stone RL, Coleman RL, Alvarez RD, Lopez-Berestein G, Sood AK, et al. 2011. Targeting the notch ligand JAGGED1 in both tumor cells and stroma in ovarian cancer. Clin Cancer Res 17: 5674-5685.

Suzuki Y, Montagne K, Nishihara A, Watabe T, Miyazono K. 2008. BMPs promote proliferation and migration of endothelial cells via stimulation of VEGF-A/VEGFR2 and angiopoietin-1/Tie2 signalling. J Biochem 143: 199-206.

Takimoto T, Wakabayashi Y, Sekiya T, Inoue N, Morita R, Ichiyama K, Takahashi R, Asakawa M, Muto G, Mori T, et al. 2010. Smad2 and Smad3 are redundantly essential for the TGF- $\beta$-mediated regulation of regulatory T plasticity and Th1 development. J Immunol 185: 842-855.

Tanaka H, Shinto O, Yashiro M, Yamazoe S, Iwauchi T, Muguruma K, Kubo N, Ohira M, Hirakawa K. 2010. Transforming growth factor $\beta$ signaling inhibitor, SB-431542, induces maturation of dendritic cells and enhances antitumor activity. Oncol Rep 24: 1637-1643.

Tuxhorn JA, McAlhany SJ, Yang F, Dang TD, Rowley DR. 2002. Inhibition of transforming growth factor- $\beta$ activity decreases angiogenesis in a human prostate cancer-reactive stroma xenograft model. Cancer Res 62: 6021-6025.

Vesely MD, Kershaw MH, Schreiber RD, Smyth MJ. 2011. Natural innate and adaptive immunity to cancer. Annu Rev Immunol 29: 235-271.

Vivier E, Ugolini S, Blaise D, Chabannon C, Brossay L. 2012. Targeting natural killer cells and natural killer T cells in cancer. Nat Rev Immunol 12: 239-252.

Walker RA, Dearing SJ, Gallacher B. 1994. Relationship of transforming growth factor $\beta 1$ to extracellular matrix and stromal infiltrates in invasive breast carcinoma. $\mathrm{Br} \mathrm{J}$ Cancer 69: 1160-1165.

Wang SE, Xiang B, Guix M, Olivares MG, Parker J, Chung CH, Pandiella A, Arteaga CL. 2008a. Transforming 
M.W. Pickup et al.

growth factor $\beta$ engages TACE and ErbB3 to activate phosphatidylinositol-3 kinase/Akt in ErbB2-overexpressing breast cancer and desensitizes cells to trastuzumab. Mol Cell Biol 28: 5605-5620.

Wang SY, Tai GX, Zhang PY, Mu DP, Zhang XJ, Liu ZH 2008b. Inhibitory effect of activin $A$ on activation of lipopolysaccharide-stimulated mouse macrophage RAW264.7 cells. Cytokine 42: 85-91.

Wei P, Zhao YG, Zhuang L, Ruben S, Sang QX. 2001. Expression and enzymatic activity of human disintegrin and metalloproteinase ADAM19/meltrin $\beta$. Biochem Biophys Res Commun 280: 744-755.

Whiteside TL, Schuler P, Schilling B. 2012. Induced and natural regulatory $\mathrm{T}$ cells in human cancer. Expert Opin Biol Ther 12: 1383-1397.

Wikström P, Stattin P, Franck-Lissbrant I, Damber JE, Bergh A. 1998. Transforming growth factor $\beta 1$ is associated with angiogenesis, metastasis, and poor clinical outcome in prostate cancer. Prostate 37: 19-29.

Wiley DM, Kim JD, Hao J, Hong CC, Bautch VL, Jin SW 2011. Distinct signalling pathways regulate sprouting angiogenesis from the dorsal aorta and the axial vein. Nat Cell Biol 13: 686-692.

Woodford-Richens KL, Rowan AJ, Gorman P, Halford S, Bicknell DC, Wasan HS, Roylance RR, Bodmer WF, Tomlinson IP. 2001. SMAD4 mutations in colorectal cancer probably occur before chromosomal instability, but after divergence of the microsatellite instability pathway. Proc Natl Acad Sci 98: 9719-9723.

Xu H, Silver PB, Tarrant TK, Chan CC, Caspi RR. 2003. Tgf$\beta$ inhibits activation and uveitogenicity of primary but not of fully polarized retinal antigen-specific memoryeffector T cells. Invest Ophthalmol Vis Sci 44: 4805-4812.

Yamashita S, Maeshima A, Kojima I, Nojima Y. 2004. Activin $\mathrm{A}$ is a potent activator of renal interstitial fibroblasts. JAm Soc Nephrol 15: 91-101.

Yang EY, Moses HL. 1990. Transforming growth factor $\beta 1$ induced changes in cell migration, proliferation, and angiogenesis in the chicken chorioallantoic membrane. J Cell Biol 111: 731-741.

Yang L, Huang J, Ren X, Gorska AE, Chytil A, Aakre M, Carbone DP, Matrisian LM, Richmond A, Lin PC, et al.
2008. Abrogation of TGF $\beta$ signaling in mammary carcinomas recruits $\mathrm{Gr}-1^{+} \mathrm{CD} 11 \mathrm{~b}^{+}$myeloid cells that promote metastasis. Cancer Cell 13: 23-35.

Yang P, Li QJ, Feng Y, Zhang Y, Markowitz GJ, Ning S, Deng Y, Zhao J, Jiang S, Yuan Y, et al. 2012. TGF- $\beta$-miR-34aCCL22 signaling-induced Treg cell recruitment promotes venous metastases of HBV-positive hepatocellular carcinoma. Cancer Cell 22: 291-303.

Yashiro R, Nagasawa T, Kiji M, Hormdee D, Kobayashi H, Koshy G, Nitta H, Ishikawa I. 2006. Transforming growth factor- $\beta$ stimulates interleukin-11 production by human periodontal ligament and gingival fibroblasts. J Clin Periodontol 33: 165-171.

Yaswen L, Kulkarni AB, Fredrickson T, Mittleman B, Schiffman R, Payne S, Longenecker G, Mozes E, Karlsson S. 1996. Autoimmune manifestations in the transforming growth factor- $\beta 1$ knockout mouse. Blood 87: 14391445.

Yoshioka Y, Ono M, Osaki M, Konishi I, Sakaguchi S. 2012. Differential effects of inhibition of bone morphogenic protein (BMP) signalling on T-cell activation and differentiation. Eur J Immunol 42: 749-759.

Yu B, Chen X, Li J, Qu Y, Su L, Peng Y, Huang J, Yan J, Yu Y, $\mathrm{Gu} \mathrm{Q}$, et al. 2013. Stromal fibroblasts in the microenvironment of gastric carcinomas promote tumor metastasis via upregulating TAGLN expression. BMC Cell Biol 14: 17.

Zhang XJ, Li Y, Tai GX, Xu GY, Zhang PY, Yang Y, Lao FX, Liu ZH. 2005. Effects of activin A on the activities of the mouse peritoneal macrophages. Cell Mol Immunol 2: 63-67.

Zhang M, Herion TW, Timke C, Han N, Hauser K, Weber KJ, Peschke P, Wirkner U, Lahn M, Huber PE. 2011. Trimodal glioblastoma treatment consisting of concurrent radiotherapy, temozolomide, and the novel TGF- $\beta$ receptor I kinase inhibitor LY2109761. Neoplasia 13: 537-549.

Zhou J, Schmid T, Schnitzer S, Brune B. 2006. Tumor hypoxia and cancer progression. Cancer Lett 237: 10-21.

Zhou J, Tai G, Liu H, Ge J, Feng Y, Chen F, Yu F, Liu Z. 2009. Activin A down-regulates the phagocytosis of lipopolysaccharide-activated mouse peritoneal macrophages in vitro and in vivo. Cell Immunol 255: 69-75. 


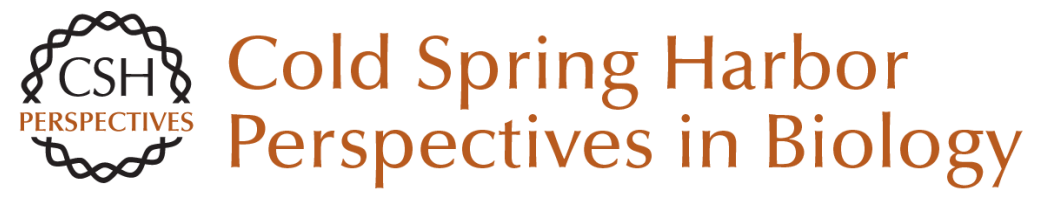

\title{
TGF- $\beta$, Bone Morphogenetic Protein, and Activin Signaling and the Tumor Microenvironment
}

\author{
Michael W. Pickup, Philip Owens and Harold L. Moses
}

Cold Spring Harb Perspect Biol 2017; doi: 10.1101/cshperspect.a022285 originally published online January 6, 2017

\section{Subject Collection The Biology of the TGF-\&\#946; Family}

TGF- $\beta$ Family Signaling in Early Vertebrate

Development

Joseph Zinski, Benjamin Tajer and Mary C. Mullins

Bone Morphogenetic Protein-Based Therapeutic

Approaches

Jonathan W. Lowery and Vicki Rosen

TGF- $\beta$ Family Signaling in Ductal Differentiation

and Branching Morphogenesis

Kaoru Kahata, Varun Maturi and Aristidis

Moustakas

TGF- $\beta$ Signaling in Control of Cardiovascular

Function

Marie-José Goumans and Peter ten Dijke

TGF- $\beta$ Family Signaling in Tumor Suppression and Cancer Progression

Joan Seoane and Roger R. Gomis

Targeting TGF- $\beta$ Signaling for Therapeutic Gain Rosemary J. Akhurst

Regulation of Hematopoiesis and Hematological Disease by TGF- $\beta$ Family Signaling Molecules Kazuhito Naka and Atsushi Hirao
TGF- $\beta$ Family Signaling in Mesenchymal

Differentiation

Ingo Grafe, Stefanie Alexander, Jonathan $R$.

Peterson, et al.

TGF- $\beta 1$ Signaling and Tissue Fibrosis

Kevin K. Kim, Dean Sheppard and Harold A.

Chapman

Bone Morphogenetic Proteins in Vascular

Homeostasis and Disease

Marie-José Goumans, An Zwijsen, Peter ten Dijke, et al.

TGF- $\beta$ Family Signaling in Epithelial

Differentiation and Epithelial-Mesenchymal

Transition

Kaoru Kahata, Mahsa Shahidi Dadras and Aristidis Moustakas

TGF- $\beta$ Family Signaling in Connective Tissue and

Skeletal Diseases

Elena Gallo MacFarlane, Julia Haupt, Harry C.

Dietz, et al.

The TGF- $\beta$ Family in the Reproductive Tract

Diana Monsivais, Martin M. Matzuk and Stephanie A. Pangas

TGF- $\beta$ Family Signaling in Drosophila Ambuj Upadhyay, Lindsay Moss-Taylor, Myung-Jun Kim, et al.

For additional articles in this collection, see http://cshperspectives.cshlp.org/cgi/collection/

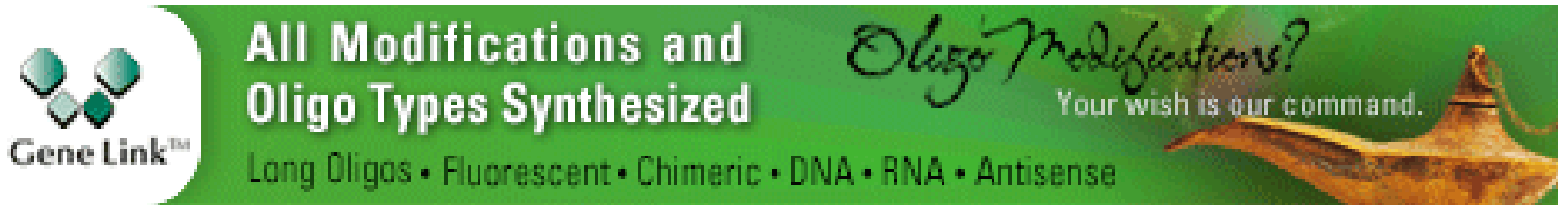


TGF- $\beta$ Family Signaling in Neural and Neuronal Differentiation, Development, and Function Emily A. Meyers and John A. Kessler
Signaling Cross Talk between TGF- $\beta /$ Smad and Other Signaling Pathways Kunxin LuO

For additional articles in this collection, see http://cshperspectives.cshlp.org/cgi/collection/

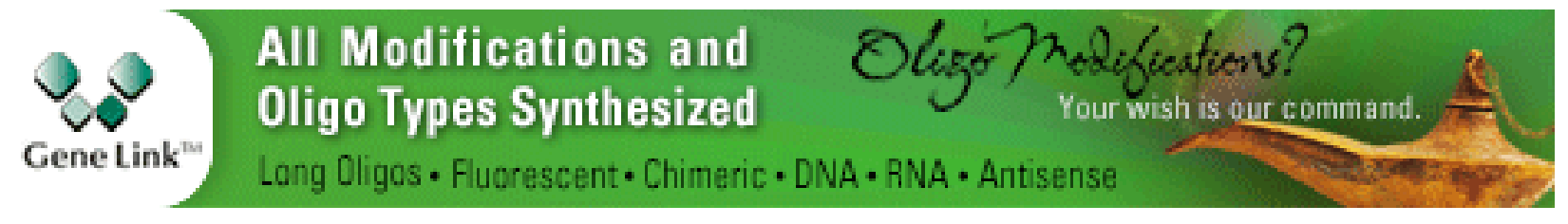

Copyright @ 2017 Cold Spring Harbor Laboratory Press; all rights reserved 